\title{
Activity and abundance of denitrifying bacteria in the subsurface biosphere of diffuse hydrothermal vents of the Juan de Fuca Ridge
}

\author{
A. Bourbonnais ${ }^{1}$, S. K. Juniper ${ }^{1}$, D. A. Butterfield ${ }^{2,3}$, A. H. Devol ${ }^{4}$, M. M. M. Kuypers ${ }^{5}$, G. Lavik ${ }^{5}$, S. J. Hallam ${ }^{6,7}$, \\ C. B. Wenk ${ }^{8}$, B. X. Chang ${ }^{9}$, S. A. Murdock ${ }^{1}$, and M. F. Lehmann ${ }^{8}$ \\ ${ }^{1}$ School of Earth and Ocean Sciences, University of Victoria, Victoria, BC V8P 5C2, Canada \\ ${ }^{2}$ Joint Institute for the Study of the Atmosphere and Ocean, University of Washington, Seattle, WA 98105-5672, USA \\ ${ }^{3}$ Pacific Marine Environmental Laboratory, National Oceanic and Atmospheric Administration, Seattle, WA 98115, USA \\ ${ }^{4}$ School of Oceanography, University of Washington, Seattle, WA 98195-7940, USA \\ ${ }^{5}$ Max Planck Institute for Marine Microbiology, Department of Biogeochemistry, 28359 Bremen, Germany \\ ${ }^{6}$ University of British Columbia, Department of Microbiology and Immunology, Vancouver, BC V6T 1Z3, Canada \\ ${ }^{7}$ Graduate Programme in Bioinformatics, University of British Columbia, Vancouver, BC V6T 1Z3, Canada \\ ${ }^{8}$ Department of Environmental Sciences, University of Basel, 4056 Basel, Switzerland \\ ${ }^{9}$ Department of Environmental Sciences, Princeton University, Princeton, NJ 08544, USA
}

Correspondence to: A. Bourbonnais (annieb@uvic.ca)

Received: 4 March 2012 - Published in Biogeosciences Discuss.: 3 April 2012

Revised: 26 September 2012 - Accepted: 1 October 2012 - Published: 22 November 2012

\begin{abstract}
Little is known about fixed nitrogen (N) transformation and elimination at diffuse hydrothermal vents where anoxic fluids are mixed with oxygenated crustal seawater prior to discharge. Oceanic $\mathrm{N}$ sinks that remove bio-available $\mathrm{N}$ ultimately affect chemosynthetic primary productivity in these ecosystems. Using ${ }^{15} \mathrm{~N}$ paired isotope techniques, we determined potential rates of fixed $\mathrm{N}$ loss pathways (denitrification, anammox) and dissimilatory nitrate reduction to ammonium (DNRA) in sulfidic hydrothermal vent fluids discharging from the subsurface at several sites at Axial Volcano and the Endeavour Segment on the Juan de Fuca Ridge. We also measured physico-chemical parameters (i.e., temperature, $\mathrm{pH}$, nutrients, $\mathrm{H}_{2} \mathrm{~S}$ and $\mathrm{N}_{2} \mathrm{O}$ concentrations) as well as the biodiversity and abundance of chemolithoautotrophic nitrate-reducing, sulfur-oxidizing $\gamma$-proteobacteria (SUP05 cluster) using sequence analysis of amplified small subunit ribosomal RNA (16S rRNA) genes in combination with taxon-specific quantitative polymerase chain reaction (qPCR) assays. Denitrification was the dominant $\mathrm{N}$ loss pathway in the subsurface biosphere of the Juan de Fuca Ridge, with rates of up to $\sim 1000 \mathrm{nmol} \mathrm{N}^{-1} \mathrm{day}^{-1}$. In comparison, anammox rates were always $<5 \mathrm{nmol} \mathrm{N1}^{-1} \mathrm{day}^{-1}$ and below the detection limit at most of the sites. DNRA rates were
\end{abstract}

up to $\sim 150 \mathrm{nmol} \mathrm{N1}^{-1} \mathrm{day}^{-1}$. These results suggest that bacterial denitrification out-competes anammox in sulfidic hydrothermal vent waters. Taxon-specific qPCR revealed that $\gamma$-proteobacteria of the SUP05 cluster sometimes dominated the microbial community (SUP05/total bacteria up to $38 \%$ ). Significant correlations were found between fixed $\mathrm{N}$ loss (i.e., denitrification, anammox) rates and in situ nitrate and dissolved inorganic nitrogen (DIN) deficits in the fluids, indicating that DIN availability may ultimately regulate $\mathrm{N}$ loss in the subsurface. Based on our rate measurements, and on published data on hydrothermal fluid fluxes and residence times, we estimated that up to $\sim 10 \mathrm{Tg} \mathrm{Nyr}^{-1}$ could globally be removed in the subsurface biosphere of hydrothermal vents systems, thus, representing a small fraction of the total marine $\mathrm{N}$ loss $\left(\sim 275\right.$ to $\left.>400 \mathrm{Tg} \mathrm{N} \mathrm{yr}^{-1}\right)$.

\section{Introduction}

Nitrogen is an essential macronutrient for all organisms, and oceanic $\mathrm{N}$ sinks that remove biologically available $\mathrm{N}$ via denitrification and anaerobic ammonium $\left(\mathrm{NH}_{4}^{+}\right)$oxidation (anammox) ultimately limit marine primary productivity. Denitrification, the stepwise reduction of nitrate $\left(\mathrm{NO}_{3}^{-}\right)$to 
$\mathrm{N}_{2}$ gas, is mediated by both heterotrophic and autotrophic bacteria and occurs in the anoxic and suboxic oceanic water-column (Codispoti et al., 2001; Lavik et al., 2009; Ward et al., 2009; Grote et al., 2012) and sediments (e.g., Christensen et al., 1987). For the past decade, anammox, i.e., the conversion of $\mathrm{NH}_{4}^{+}$and nitrite $\left(\mathrm{NO}_{2}^{-}\right)$to $\mathrm{N}_{2}$ gas by autotrophic anaerobic bacteria, has also been reported to account for a significant part of the $\mathrm{N}$ loss in oceanic anoxic zones (Dalsgaard et al., 2003; Kuypers et al., 2003; 2005; Lam et al., 2009; Jensen et al., 2011). While studies of $\mathrm{N}$ cycling in marine ecosystems have concentrated on oxygen-deficient waters in coastal and open ocean oxygen minimum zones and sediments (see references above), little is known about metabolic processes and bacterially-mediated $\mathrm{N}$-cycle dynamics that occur in the extensive subsurface biosphere of hydrothermal vent systems.

Hydrothermal fluids are formed when seawater circulates through the upper oceanic crust at mid-ocean ridges where it is heated and chemically altered in the subsurface and rises back to the seafloor. The fluids are either discharged directly through high-temperature vents (up to $\sim 400^{\circ} \mathrm{C}$ ) or through diffuse, low temperature (low-T) vents (typically $<50^{\circ} \mathrm{C}$ ) following subsurface mixing with crustal seawater. Ecosystems at seafloor vents are sustained by biomass production through chemolithoautotrophic bacteria and archaea that gain their metabolic energy primarily from the oxidation of reduced sulfur species and molecular hydrogen $\left(\mathrm{H}_{2}\right)$ present in vent fluids (e.g., Jannasch and Mottl, 1985).

Observations of abundant and diverse microbial populations at low-T vents (e.g., Huber et al., 2002, 2007; Alain et al., 2004), as well as $\mathrm{NO}_{3}^{-}$removal in the sub-seafloor mixing zone (Butterfield et al, 2004), and stable isotope measurements of dissolved $\mathrm{N}$ species in hydrothermal fluids of the Juan de Fuca Ridge (Bourbonnais et al., 2012) provide insight into microbial $\mathrm{N}$ processes in the subsurface biosphere. There are also more conclusive evidences for both denitrification and anammox activity in hydrothermal vent systems. For example, Wang et al. (2009) detected an almost complete spectrum of the functional genes required for denitrification, i.e., nar $\left(\mathrm{NO}_{3}^{-}\right.$reductase $)$, nir $\left(\mathrm{NO}_{2}^{-}\right.$ reductase), norB (nitric oxide (NO) reductase) and nos $Z$ (nitrous oxide $\left(\mathrm{N}_{2} \mathrm{O}\right)$ reductase), in DNA extracted from hydrothermal vent chimneys of the Juan de Fuca Ridge using functional gene arrays (GeoChip). Byrne et al. (2009) documented, for the first time, the presence and activity of anammox bacteria in hydrothermal vents of the Mid-Atlantic Ridge. Their reported anammox rates, measured from an aqueous mixture of chimney samples, were low (up to $60 \mathrm{nmolN}^{-1} \mathrm{day}^{-1}$ ). Major metabolic pathways for fixed $\mathrm{N}$ loss have never directly been quantified in discharging hydrothermal fluids, and environmental controls on the activity and abundance of microbial populations that are responsible for fixed $\mathrm{N}$ loss processes as these fluids rise through the subsurface remain to be determined.
Information on the specific microbial agents mediating $\mathrm{N}$ loss processes in the subsurface biosphere of hydrothermal vent systems is still emerging. Culture-independent molecular surveys of microbial diversity in these systems have identified 16S rRNA gene sequences affiliated with known autotrophic denitrifiers (e.g., López-García et al., 2002; Hodges and Olson, 2009). $\varepsilon$-proteobacteria are generally the dominant group of chemolithoautotrophs in hydrothermal vent fluids (López-García et al., 2003; Alain et al., 2004; Nakagawa et al., 2005a; Huber et al., 2007; 2010). Cultivation studies have confirmed that many of these $\varepsilon$-proteobacteria retain the capacity to oxidize reduced sulfur species and hydrogen $\left(\mathrm{H}_{2}\right)$, while reducing $\mathrm{NO}_{3}^{-}$or other electron acceptors (e.g., $\mathrm{O}_{2}, \mathrm{~S}^{0}$ and $\mathrm{S}_{2} \mathrm{O}_{3}^{-}$) (Nakagawa et al., 2005a; Takai et al., 2006).

At least one denitrifying $\gamma$-proteobacterial group is also known from hydrothermal environments. 16S rRNA gene sequences affiliated with SUP05 $\gamma$-proteobacteria, related to the gill symbionts of deep-sea clams and mussels, have been identified as major constituents of redox-active hydrothermal vent plumes (Sunamura et al., 2004; German et al., 2010). SUP05 was first described in the Suiyo Seamount hydrothermal plume by Sunamura et al. (2004) and later associated with oxygen-deficient marine waters in the eastern tropical South Pacific (Stevens and Ulloa, 2008), the Namibian upwelling system (Lavik et al., 2009) and the northeastern subarctic Pacific (Walsh et al., 2009; Zaikova et al., 2010). Ecophysiological studies, metagenome assembly and gene expression profiling indicate that SUP05 couples the oxidation of reduced sulfur species with $\mathrm{NO}_{3}^{-}$reduction (Lavik et al., 2009; Walsh et al., 2009; Stewart et al., 2012). Based on these observations, SUP05 populations would be expected to inhabit subsurface conduits and mixing zones that supply diffuse hydrothermal vents. In these ramified interstitial spaces, sulfide concentrations are high and there is episodic re-supply of $\mathrm{NO}_{3}^{-}$from entrained crustal seawater.

In the present study, we examined the relative importance of rates of denitrification, anammox and dissimilative $\mathrm{NO}_{3}^{-}$ reduction to $\mathrm{NH}_{4}^{+}$(DNRA) in relation to specific microbial agents in diffuse hydrothermal vent fluids of the Juan de Fuca Ridge, using a combination of ${ }^{15} \mathrm{~N}$ paired isotope labelling, 16S rRNA gene clone library sequencing and quantitative polymerase chain reaction (qPCR) methods. We then used these results to assess the diversity and abundance of potential sulfur-oxidizing denitrifiers and evaluated chemical and physical constraints on the activity and abundance of the microbial communities that mediate biological $\mathrm{N}$ loss in the subsurface of hydrothermal vents. Finally, we extended our interpretation to consider the role of the subsurface hydrothermal biosphere in modulating geochemical $\mathrm{N}$ fluxes in the deep ocean. 


\section{Material and methods}

\subsection{Site description and sample collection}

Discharging fluids were sampled at different diffuse vent sites on Axial Volcano and the Endeavour Segment, both located on the Juan de Fuca Ridge, in the northeast Pacific Ocean (Fig. 1). Sampling took place during 4 summer/autumn cruises in August 2007, June and August-September 2008 and June 2009 using submersibles supported by the CCGS John P. Tully and the R/V Atlantis during the New Millennium Observatory (NeMO) and Endeavour-Axial Geochemistry and Ecology Research (EAGER) Projects.

The latitude/longitude coordinates of sampled vents are given in Table 1. At Endeavour Segment, diffuse vents were sampled in the Main Endeavour (ME), High Rise (HR) and Mothra (M) vent fields at depths of 2100-2300 m. Sediments that are now buried by ridge basalts are thought to be the origin of anomalously high methane $\left(\mathrm{CH}_{4}\right)$ and $\mathrm{NH}_{4}^{+}$ concentrations observed in vent fluids at this site (Lilley et al., 1993). Axial Volcano is the volcanically most active site on the Juan de Fuca Ridge, and rises $700 \mathrm{~m}$ above the ridge crest. It has a rectangular shaped caldera $(3 \times$ $8 \mathrm{~km})$ that lies between two rift zones, with vents located near the caldera fault and along the rift zones, at depths of 1500 to $1550 \mathrm{~m}$. The diffuse vents were sampled in the ASHES, CASM and South Rift Zone vent fields. A January-February 1998 seafloor volcanic eruption covered most of the South Rift Zone vent field with volcanic material and resulted in the formation of new vents (Embley et al., 1999). A more recent eruption was detected in July 2011 (Chadwick et al., 2012). Hydrothermal fluids were sampled using two different devices. During the June 2008 cruise, low and high temperature fluids were collected using a suction sampler, that pumped water into $2 \mathrm{~L}$ acrylic jars mounted on the remotely operated vehicle (ROV) ROPOS. The jars were flushed several times prior to sample collection. During all other cruises, samples were collected using the Hydrothermal Fluid and Particle Sampler (HFPS) mounted on the ROV JASON or the deep submergence vehicle (DSV) ALVIN. HFPS samples were collected either in collapsible Tedlar ${ }^{\circledR}$ bags with valves (of up to $\sim 600 \mathrm{ml}$ volume each), or in PVC piston samplers with Teflon spring seals. The average inlet temperature during sample collection was calculated from in situ temperature recorded at $1 \mathrm{~Hz}$.

During the June 2008 cruise, samples for denitrification rate measurements were transferred without contact with the atmosphere to $500 \mathrm{ml}$ amber bottles, capped with silicone stoppers containing two lengths of 1/16-inch nylon tubing with valves and connected to the suction jar by 1/8- and 5/16-inch Tygon tubes, as described in Devol et al. (2006). During the August-September 2008 cruise, ${ }^{15} \mathrm{~N}$-labelling experiments for rate determinations were directly conducted in the Tedlar ${ }^{\circledR}$ collapsible bags. Samples

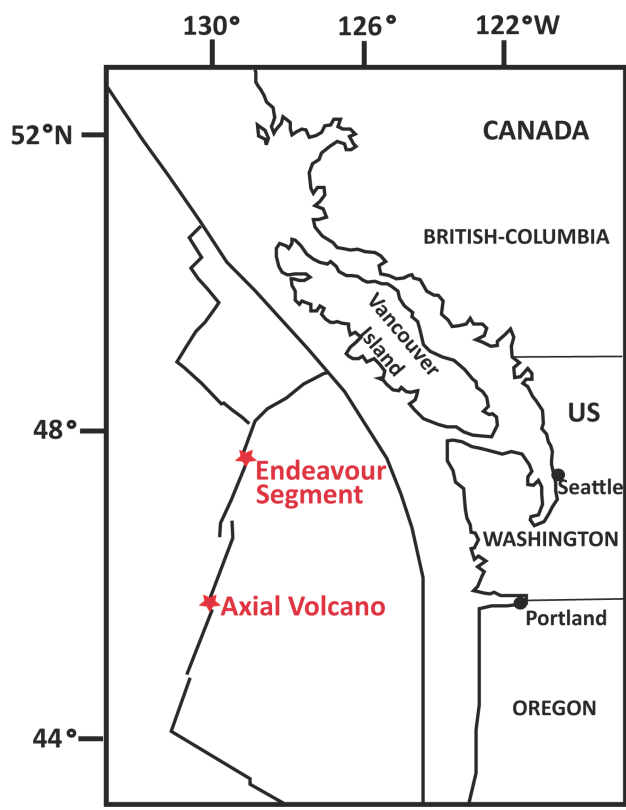

Fig. 1. Map of the hydrothermal vent fields, i.e., Axial Volcano and Endeavour Segment on the Juan de Fuca Ridge (northeast Pacific Ocean), indicated by red stars. See Table 1 for precise location of the sampled vent sites.

were stored for typically less than 1 hour in a cool room after each dive until further processing. Subsamples were taken from the collapsible bags using a syringe and transferred into acid-washed and DI-rinsed 60-ml HDPE brown bottles for nutrient concentration determination. All nutrient sub-samples were purged with $\mathrm{N}_{2}$ gas for at least $10 \mathrm{~min}$ in order to remove hydrogen sulfide $\left(\mathrm{H}_{2} \mathrm{~S}\right)$, which potentially interferes with colorimetric nutrient analyses. The purged nutrient samples were kept frozen at $-20^{\circ} \mathrm{C}$ until analysis.

\subsection{Physico-chemical properties}

Chemical analyses of fluid samples were conducted on board within less than $\sim 8$ hours after sampling. $\mathrm{pH}$ was analysed potentiometrically with a standard deviation of $0.01 \mathrm{pH}$ unit. Magnesium $\left(\mathrm{Mg}^{2+}\right)$ concentrations were analyzed as in Butterfield et al. (2004). Hydrogen sulfide and $\mathrm{NH}_{4}^{+}$concentrations were analysed using standard colorimetric methods (methylene blue (Cline, 1969) and indophenol blue (Solorzano, 1969) methods, respectively), with standard precisions of $4 \%$ and $7 \%$, respectively. $\mathrm{NO}_{\mathrm{x}}$ $\left(\mathrm{NO}_{3}^{-}\right.$and $\left.\mathrm{NO}_{2}^{-}\right)$was measured by chemiluminescence, i.e., reduction to $\mathrm{NO}$ in a heated solution of acidic vanadium (III) and subsequent detection of NO (Braman and Hendrix, 1989), with an analytical precision for replicate analyses of $\pm 0.2 \mu \mathrm{moll}^{-1}$. Nitrate, $\mathrm{NO}_{2}^{-}$, and phosphate $\left(\mathrm{PO}_{4}^{3-}\right)$ were also analysed on shore using a colorimetric Astoria II nutrient autoanalyser following methods described 
Table 1. Physico-chemical and microbiological properties of the sampled vent fluids at Axial Volcano (AV) and the Endeavour Segment (ES) on the Juan de Fuca Ridge. Values shown are means \pm one standard deviation for all samples collected from a given vent on each cruise. 2008a and 2008b refers to samples collected during the June and August-September 2008 cruises, respectively.

\begin{tabular}{|c|c|c|c|c|c|c|c|c|c|c|c|}
\hline Field & Vent & Year & Latitude & Longitude & $\begin{array}{l}\text { Depth } \\
(\mathrm{m})\end{array}$ & $n$ & $\begin{array}{l}\text { Temp. } \\
\left({ }^{\circ} \mathrm{C}\right)\end{array}$ & $\mathrm{pH}$ & $\begin{array}{l}{\left[\mathrm{Mg}^{2+}\right]} \\
\left(\mathrm{mmol} \mathrm{kg}^{-1}\right)\end{array}$ & $\begin{array}{l}{\left[\mathrm{N}_{2} \mathrm{O}\right]} \\
\left(\mathrm{nmoll}^{-1}\right)\end{array}$ & $\begin{array}{l}{\left[\mathrm{H}_{2} \mathrm{~S}\right]} \\
\left(\mu \mathrm{mol} 1^{-1}\right)\end{array}$ \\
\hline AV & Bag City & 2007 & 45.92 & 129.99 & 1533 & 3 & $13.7 \pm 0.9$ & $6.5 \pm 0.1$ & $50.5 \pm 1.3$ & na & $39.3 \pm 19.3$ \\
\hline AV & Cloud Pit & 2007 & 45.93 & 129.98 & 1521 & 3 & $6.5 \pm 0.2$ & $6.9 \pm 0.1$ & $52.4 \pm 0.1$ & na & $76.5 \pm 130.3$ \\
\hline AV & Gollum & 2007 & 45.93 & 130.01 & 1544 & 2 & $22.0 \pm 0.5$ & 5.4 & $50.5 \pm 0.1$ & na & $154.3 \pm 24.5$ \\
\hline $\mathrm{AV}$ & Marker 113 & 2007 & 45.92 & 129.99 & 1523 & 3 & $31.2 \pm 0.4$ & $5.7 \pm 0.2$ & $49.9 \pm 0.9$ & na & $1324.6 \pm 71.1$ \\
\hline $\mathrm{AV}$ & Bag City & $2008 b$ & 45.92 & 129.99 & 1532 & 3 & $11.2 \pm 0.0$ & $6.5 \pm 0.2$ & $51.5 \pm 0.1$ & na & $55.3 \pm 48.4$ \\
\hline AV & Cloud Pit & $2008 b$ & 45.93 & 129.98 & 1522 & 4 & $6.8 \pm 0.0$ & $6.9 \pm 0.0$ & $52.6 \pm 0.0$ & na & $1.9 \pm 0.3$ \\
\hline AV & Marker 33 & $2008 b$ & 45.93 & 130.98 & 1520 & 4 & $18.5 \pm 2.1$ & $5.8 \pm 0.1$ & $47.8 \pm 0.7$ & na & $434.0 \pm 43.9$ \\
\hline $\mathrm{AV}$ & Marker 113 & $2008 b$ & 45.92 & 129.99 & 1521 & 3 & $23.5 \pm 3.5$ & $6.0 \pm 0.1$ & $51.1 \pm 0.6$ & na & $947.0 \pm 176.3$ \\
\hline AV & Gollum & 2009 & 45.93 & 130.01 & 1542 & 5 & $14.2 \pm 1.2$ & $5.7 \pm 0.0$ & $51.7 \pm 0.2$ & $256.8 \pm 9.4$ & $89.6 \pm 11.6$ \\
\hline AV & Hermosa & 2009 & 45.93 & 129.98 & 1519 & 3 & $37.0 \pm 4.1$ & $5.6 \pm 0.3$ & $51.1 \pm 0.9$ & $78.0 \pm 4.3$ & $253.2 \pm 160.3$ \\
\hline AV & Marker 33 & 2009 & 45.93 & 129.98 & 1520 & 4 & $34.4 \pm 0.9$ & $5.5 \pm 0.0$ & 41.9 & $214.4 \pm 0.4$ & $711.7 \pm 19.0$ \\
\hline $\mathrm{AV}$ & Marker 113 & 2009 & 45.92 & 129.99 & 1521 & 4 & $29.9 \pm 5.0$ & $6.1 \pm 0.1$ & $50.8 \pm 0.4$ & $11.3 \pm 9.4$ & $1020.0 \pm 194.2$ \\
\hline AV & Bkgd & 2009 & 45.90 & 130.00 & $>1200$ & 6 & $3.0 \pm 0.5$ & $7.1 \pm 0.4$ & $52.4 \pm 0.3$ & na & 0.4 \\
\hline $\mathrm{ES}$ & Clam bed & $2008 \mathrm{a}$ & 47.96 & 129.09 & 2188 & 1 & $21.2 \pm 4$ & na & na & na & na \\
\hline ES-ME & Easter Island & $2008 \mathrm{a}$ & 47.95 & 129.10 & 2199 & 2 & 20 & na & na & na & na \\
\hline ES-ME & Hulk & $2008 \mathrm{a}$ & 47.95 & 129.10 & 2201 & 2 & 25 & na & na & na & na \\
\hline ES-M & Cauldron & $2008 b$ & 47.93 & 129.11 & 2249 & 3 & $36.3 \pm 4.7$ & $6.4 \pm 0.1$ & $47.1 \pm 0.5$ & na & $219.6 \pm 61.0$ \\
\hline ES-ME & Easter Island & $2008 b$ & 47.95 & 129.10 & 2197 & 4 & $16.6 \pm 3.6$ & $6.7 \pm 0$ & $50.8 \pm 0.1$ & na & $11.9 \pm 3.7$ \\
\hline ES-HR & Godzilla & $2008 b$ & 47.97 & 129.09 & 2135 & 3 & $21.7 \pm 8.6$ & $6.2 \pm 0.3$ & $49.6 \pm 1.7$ & na & $169.6 \pm 126.5$ \\
\hline ES-ME & Hulk & $2008 b$ & 47.95 & 129.10 & 2197 & 3 & $16.4 \pm 1.7$ & $6.5 \pm 0.1$ & $50.7 \pm 0.6$ & na & $92.4 \pm 8.2$ \\
\hline ES-HR & Fairy Castle & 2009 & 47.97 & 129.09 & 2157 & 2 & $23.4 \pm 1.8$ & 6.2 & $49.3 \pm 0.2$ & $346.5 \pm 4.3$ & $245.0 \pm 35.4$ \\
\hline ES-ME & Hulk & 2009 & 47.95 & 129.10 & 2198 & 4 & $29.5 \pm 10.6$ & $6.3 \pm 0.3$ & $48.3 \pm 1.9$ & $\mathrm{BDL}$ & $212.5 \pm 132.7$ \\
\hline ES-M & Phang & 2009 & 47.92 & 129.11 & 2277 & 5 & $24.1 \pm 1.7$ & $6.5 \pm 0.3$ & $47.5 \pm 2.0$ & $107.0 \pm 14.6$ & $255.6 \pm 133.6$ \\
\hline ES & Bkgd & 2009 & 48.00 & 129.10 & $>2000$ & 8 & $2.2 \pm 0.3$ & $7.3 \pm 0.2$ & $52.7 \pm 0.4$ & na & 1.0 \\
\hline
\end{tabular}

$n$ is the number of sub-samples

na means not analyzed

in Barwell-Clarke and Whitney (1996). Dissolved $\mathrm{NO}_{\mathrm{x}}$ concentrations measured colorimetrically and by chemiluminesce were generally in good agreement. Nitrous oxide concentrations were measured onboard immediately after sample collection. Replicates of $25 \mathrm{ml}$ fluid samples and blanks (DI water only) were anaerobically transferred into $60 \mathrm{ml}$ syringes prefilled with $12 \mathrm{ml}$ of ultra-pure He, shaken for $10 \mathrm{~min}$ to ensure complete equilibration, and the gas phase was injected into $12 \mathrm{ml}$ evacuated exetainers and analysed on a Varian CP-3800 gas chromatograph equipped with an electron capture detector (ECD). Calibration curves were constructed from five serial two-fold dilutions of a concentrated $\mathrm{N}_{2} \mathrm{O}$ standard $\left(\sim 1250 \mathrm{nmol} \mathrm{N}_{2} \mathrm{Ol}^{-1}\right)$ from a reference ultra-pure $\mathrm{N}_{2} \mathrm{O}$ gas tank. Dissolved $\left[\mathrm{N}_{2} \mathrm{O}\right]$ was calculated using the Weiss and Price (1980) parametric equation for the solubility of $\mathrm{N}_{2} \mathrm{O}$ in seawater, accounting for any blank contribution. One to five sub-samples were collected at each sampling site (for all physico-chemical parameters except $\mathrm{N}_{2} \mathrm{O}$ ) during each dive and, where applicable, only the average and standard deviation for all sub-samples at a given site is reported.

\subsection{Denitrification, anammox and DNRA rates}

During the two 2008 cruises, isotopically-labelled incubations were conducted at the measured in situ sample temperatures in $500 \mathrm{ml}$ amber glass bottles or Tedlar ${ }^{\circledR}$ bags. We followed the Devol et al. (2006) protocol, with some modifications. The bottles (i.e. one bottle for each time point) for the June 2008 samples were pre-incubated for $12 \mathrm{~h}$ before the start of the incubations to remove any oxygen from seawater entrained during sampling by the suction pump. All other samples (August-September 2008) were not pre-incubated. Anoxia in the samples was verified by an Oxoid anaerobic resazurin indicator (BR0055). Added ${ }^{15} \mathrm{~N}_{-\mathrm{NO}_{3}^{-}}\left(\sim 10 \mu \mathrm{mol}^{-1}\right)$ never represented more than $46 \%$ of the ambient $\mathrm{NO}_{3}^{-}$concentration (Table 1). At 3 different time points (between 0 and $\sim 48 \mathrm{~h}$ ) $\sim 125 \mathrm{ml}$ of sample was transferred, without contact with the atmosphere, into $250 \mathrm{ml}$ evacuated glass bottles (i.e., two bottles (June 2008) or one bottle (August-September 2008) for each time point), poisoned with $100 \mu$ of saturated mercuric chloride $\left(\mathrm{HgCl}_{2}\right)$ and equipped with gas tight $9 \mathrm{~mm}$ bore Louwers-Hapert O-ring valves (Emerson et al., 1999). In the shore-based laboratory, the flasks were weighed and the dissolved gases in the water samples were equilibrated with the headspace in a constant temperature water bath, overnight. The liquid was then removed using a vacuum pump, leaving most (>95\%) 
Table 1. (continued) Physico-chemical properties of the sampled vent fluids at Axial Volcano and the Endeavour Segment on the Juan de Fuca Ridge.

\begin{tabular}{|c|c|c|c|c|c|c|c|c|c|}
\hline Field & Vent & Year & $\begin{array}{l}{\left[\mathrm{PO}_{4}^{3-}\right]} \\
\left(\mu \mathrm{moll}^{-1}\right)\end{array}$ & $\begin{array}{l}{\left[\mathrm{NO}_{3}^{-}\right.} \\
\left.+\mathrm{NO}_{2}^{-}\right] \\
\left(\mu \mathrm{moll}^{-1}\right)\end{array}$ & $\begin{array}{l}{\left[\mathrm{NO}_{3}^{-}\right]} \\
\text {deficit } \\
\left(\mu \mathrm{mol} 1^{-1}\right)\end{array}$ & $\begin{array}{l}{\left[\mathrm{NH}_{4}^{+}\right]} \\
\left(\mu \mathrm{mol} \mathrm{l}^{-1}\right)\end{array}$ & $\begin{array}{l}{\left[\mathrm{NH}_{4}^{+}\right]} \\
\text {deficit } \\
\left(\mu \mathrm{mol} 1^{-1}\right)\end{array}$ & $\begin{array}{l}\text { DIN } \\
\text { deficit } \\
\left(\mu \mathrm{mol} 1^{-1}\right)\end{array}$ & $\begin{array}{l}\text { Cell count } \\
/ \mathrm{ml}^{-1}\end{array}$ \\
\hline AV & Bag City & 2007 & $3.5 \pm 0.5$ & $8.6 \pm 2.7$ & $31.4 \pm 4.7$ & $1.9 \pm 0.7$ & $-1.4 \pm 3.0$ & $30.0 \pm 4.8$ & na \\
\hline AV & Cloud Pit & 2007 & $3.1 \pm 0.2$ & $18.1 \pm 1.8$ & $23.4 \pm 4.2$ & $1.4 \pm 0.3$ & $-1.4 \pm 3.0$ & $22.0 \pm 4.2$ & na \\
\hline AV & Gollum & 2007 & $4.2 \pm 0.2$ & $26.7 \pm 0.4$ & $13.3 \pm 3.7$ & $3.1 \pm 0.9$ & $-2.6 \pm 3.0$ & $10.7 \pm 3.8$ & na \\
\hline AV & Marker 113 & 2007 & $3.5 \pm 0.0$ & $1.6 \pm 0.5$ & $37.9 \pm 3.7$ & $12.6 \pm 0.4$ & $-11.9 \pm 2.9$ & $26.0 \pm 3.8$ & na \\
\hline AV & Bag City & $2008 b$ & $2.6 \pm 0.1$ & $9.1 \pm 3.0$ & $30.6 \pm 4.8$ & $1.8 \pm 0.1$ & $-0.4 \pm 3.0$ & $30.1 \pm 4.8$ & $(1.7 \pm 0.6) \times 10^{5}$ \\
\hline AV & Cloud Pit & $2008 b$ & $3.2 \pm 1.7$ & $16.0 \pm 0.4$ & $24.5 \pm 3.9$ & $1.4 \pm 0.2$ & $-0.3 \pm 3.0$ & $24.2 \pm 3.9$ & $(5.3 \pm 0.4) \times 10^{5}$ \\
\hline AV & Marker 33 & $2008 b$ & $3.9 \pm 0.9$ & $31.2 \pm 1.6$ & $5.6 \pm 3.9$ & $1.9 \pm 0.6$ & $0.4 \pm 2.8$ & $6.0 \pm 3.9$ & $(2.0 \pm 0.5) \times 10^{5}$ \\
\hline AV & Marker 113 & $2008 b$ & $3.5 \pm 0.4$ & $15.8 \pm 4.6$ & $23.6 \pm 5.9$ & $10.7 \pm 3.3$ & $-9.2 \pm 4.4$ & $14.4 \pm 6.8$ & $(8.0 \pm 0.3) \times 10^{5}$ \\
\hline AV & Gollum & 2009 & na & $14.1 \pm 5.2$ & $15.5 \pm 5.2$ & $2.6 \pm 0.7$ & $-1.3 \pm 3.0$ & $14.1 \pm 5.2$ & $(2.6 \pm 1.0) \times 10^{4}$ \\
\hline AV & Hermosa & 2009 & na & $41.7 \pm 2.2$ & $-2.4 \pm 4.4$ & $1.9 \pm 1.1$ & $4.4 \pm 3.1$ & $-2.9 \pm 4.5$ & $(1.3 \pm 0.5) \times 10^{4}$ \\
\hline AV & Marker 33 & 2009 & na & $15.7 \pm 2.0$ & $16.5 \pm 3.6$ & $4.4 \pm 0.2$ & $-3.6 \pm 2.4$ & $15.8 \pm 3.7$ & $(2.8 \pm 0.5) \times 10^{5}$ \\
\hline AV & Marker 113 & 2009 & na & $7.1 \pm 3.4$ & $32.0 \pm 5.0$ & $10.2 \pm 3.1$ & $-8.6 \pm 4.2$ & $23.4 \pm 5.9$ & $(1.1 \pm 0.2) \times 10^{6}$ \\
\hline AV & Bkgd & 2009 & 2.7 & $41.5 \pm 3.8$ & 0 & $0.4 \pm 0.3$ & $-0.4 \pm 0.3$ & $-0.4 \pm 5.4$ & na \\
\hline ES & Clam bed & $2008 \mathrm{a}$ & na & 39.9 & na & 0.9 & na & na & $(9.2 \pm 0.3) \times 10^{5}$ \\
\hline ES-ME & Easter Island & $2008 \mathrm{a}$ & na & 37.9 & na & 4.3 & na & na & $(2.3 \pm 0.1) \times 10^{5}$ \\
\hline ES-ME & Hulk & $2008 \mathrm{a}$ & na & 36.3 & na & 3.3 & na & na & $(2.3 \pm 0.1) \times 10^{5}$ \\
\hline ES-M & Cauldron & $2008 b$ & $3.2 \pm 0.8$ & $29.2 \pm 3.3$ & $7.2 \pm 4.8$ & $47.6 \pm 3.2$ & $-5.6 \pm 5.2$ & $1.6 \pm 6.1$ & $(4.7 \pm 1.0) \times 10^{5}$ \\
\hline ES-ME & Easter Island & $2008 b$ & $2.5 \pm 0.6$ & $17.8 \pm 4.7$ & $21.4 \pm 5.1$ & $15.2 \pm 1.2$ & $0.1 \pm 2.6$ & $21.5 \pm 5.6$ & $(1.3 \pm 0.3) \times 10^{5}$ \\
\hline ES-HR & Godzilla & $2008 b$ & $1.5 \pm 0.2$ & $34.1 \pm 3.1$ & $4.1 \pm 5.0$ & $56.3 \pm 34.1$ & $-4.5 \pm 44.3$ & $-0.4 \pm 35.3$ & $(2.6 \pm 0.6) \times 10^{5}$ \\
\hline ES-ME & Hulk & $2008 b$ & $2.4 \pm 0.1$ & $29.6 \pm 1.3$ & $9.5 \pm 3.9$ & $21.7 \pm 2.5$ & $-5.8 \pm 5.5$ & $3.7 \pm 5.1$ & $(2.8 \pm 0.5) \times 10^{5}$ \\
\hline ES-HR & Fairy Castle & 2009 & na & $28.0 \pm 1.3$ & $10.0 \pm 2.3$ & $41.4 \pm 3.8$ & $15.5 \pm 6.8$ & $25.5 \pm 9.6$ & $(6.1 \pm 2.2) \times 10^{4}$ \\
\hline ES-ME & Hulk & 2009 & na & $27.8 \pm 2.6$ & $9.4 \pm 3.6$ & $38.0 \pm 20.5$ & $-3.8 \pm 25.6$ & $5.6 \pm 21.4$ & $(1.0 \pm 0.4) \times 10^{5}$ \\
\hline ES-M & Phang & 2009 & na & $30.4 \pm 4.1$ & $6.2 \pm 4.7$ & $42.7 \pm 20.8$ & $-3.3 \pm 25.6$ & $2.9 \pm 21.5$ & $(4.4 \pm 1.5) \times 10^{4}$ \\
\hline $\mathrm{ES}$ & Bkgd & 2009 & 3.1 & $40.6 \pm 2.0$ & 0 & $1.4 \pm 2.2$ & $-1.4 \pm 2.2$ & $-1.4 \pm 3.7$ & $(2.5 \pm 0.9) \times 10^{4}$ \\
\hline
\end{tabular}

of the gas behind. The remaining gas was transferred to a stainless steel tube immersed in liquid He. Water and $\mathrm{CO}_{2}$ were cryogenically trapped during the gas extraction process and oxygen was removed using a hot copper furnace, to avoid isobaric interference during the analysis of ${ }^{30} \mathrm{~N}_{2}$. A known amount of ${ }^{36} \mathrm{Ar}$ was also added during this step to determine the absolute concentrations of $\mathrm{Ar}$ in the samples. Gas samples were then analysed for mass ratios 28:40, 29:28; 30:28 and 36:40, relative to in-house standards with known gas ratios, on a Finnigan Delta XL mass spectrometer at the University of Washington. Average precision based on duplicate measurements was $0.6 \%$ for the $\mathrm{N}_{2} / \mathrm{Ar}$ ratio, $0.01 \%$ for $\delta^{29} \mathrm{~N}_{2}$ and $2 \%$ for $\delta^{30} \mathrm{~N}_{2}$ (where $\delta^{30} \mathrm{~N}_{2}=\left[\left(R_{\text {sample }}^{30} / R_{\text {standard }}^{30}\right)-1\right] \times 1000$ and $\delta^{29} \mathrm{~N}_{2}=\left[\left(R_{\text {sample }}^{29} / \mathrm{R}_{\text {standard }}^{29}\right)-1\right] \times 1000 ; R$ represents the molar ratio of mass 29 (or mass 30) to mass $28 \mathrm{~N}_{2}$ in a sample or in the standard (air), respectively). Denitrification rates were calculated according to Devol et al. (2006) and Ward et al. (2009).

Denitrification, anammox and DNRA rates were also measured in duplicate during the 2009 cruise following a slightly different protocol. $\sim 20 \mu \mathrm{mol}^{-1}{ }^{15} \mathrm{~N}$-labelled $\mathrm{NO}_{3}^{-}$, $\mathrm{NO}_{2}^{-}$or $\mathrm{NH}_{4}^{+}$were added to the hydrothermal vent fluids as soon as possible after sample collection. Sample vials were then purged with helium (He) and sample aliquots were anaerobically transferred to $12 \mathrm{ml}$ exetainers and incubated at the measured in situ temperature without headspace (see Kuypers et al., 2005) for up to $\sim 53 \mathrm{~h}$. About $10 \mu \mathrm{moll}^{-1}$ natural-abundance $\mathrm{NH}_{4}^{+}$was also added in the ${ }^{15} \mathrm{~N}_{-} \mathrm{NO}_{2}^{-}$ experiments. At specific time points, $1 \mathrm{ml}$ of water was removed and replaced with $\mathrm{He}$ and a saturated $\mathrm{HgCl}_{2}$ solution was added to stop biological activity. The production of ${ }^{29} \mathrm{~N}_{2}$ and ${ }^{30} \mathrm{~N}_{2}$ for all labelled experiments was determined in the headspace through isotope ratio mass spectrometry (IRMS) measurements (VG Optima Micromass) using air as a standard. Denitrification and anammox rates were calculated according to Nielsen (1992) and Thamdrup et al. (2006), considering only the linear portions of the curves. The errors on the slopes of the regression lines were calculated (see Figs. 2 and 3).

For DNRA rate measurements, $6 \mathrm{ml}$ exetainers were filled with fluid samples (from the $12 \mathrm{ml}$ exetainers above, after incubating with ${ }^{15} \mathrm{~N}_{-} \mathrm{NO}_{3}^{-}$or $\mathrm{NO}_{2}^{-}$and measuring the ${ }^{29} \mathrm{~N}_{2}$ and ${ }^{30} \mathrm{~N}_{2}$ in the headspace for denitrification rates). About $5 \mu \mathrm{moll}^{-1}{ }^{14} \mathrm{NH}_{4}^{+}$was added to increase the background $\mathrm{NH}_{4}^{+}$concentration and the headspace was flushed with $5 \mathrm{~mL}$ He gas using a Hamilton gas-tight syringe to remove labelled ${ }^{15} \mathrm{~N}_{2}$ product from the previous experiment. $1 \mathrm{ml}$ of water was removed and replaced with $\mathrm{He}$, following which $200 \mu \mathrm{l}$ of a freshly made sodium hypobromite solution was added to the exetainer to convert $\mathrm{NH}_{4}^{+}$to $\mathrm{N}_{2}$. The solution was mixed using a vortex mixer for at least 30 seconds. In addition, three 

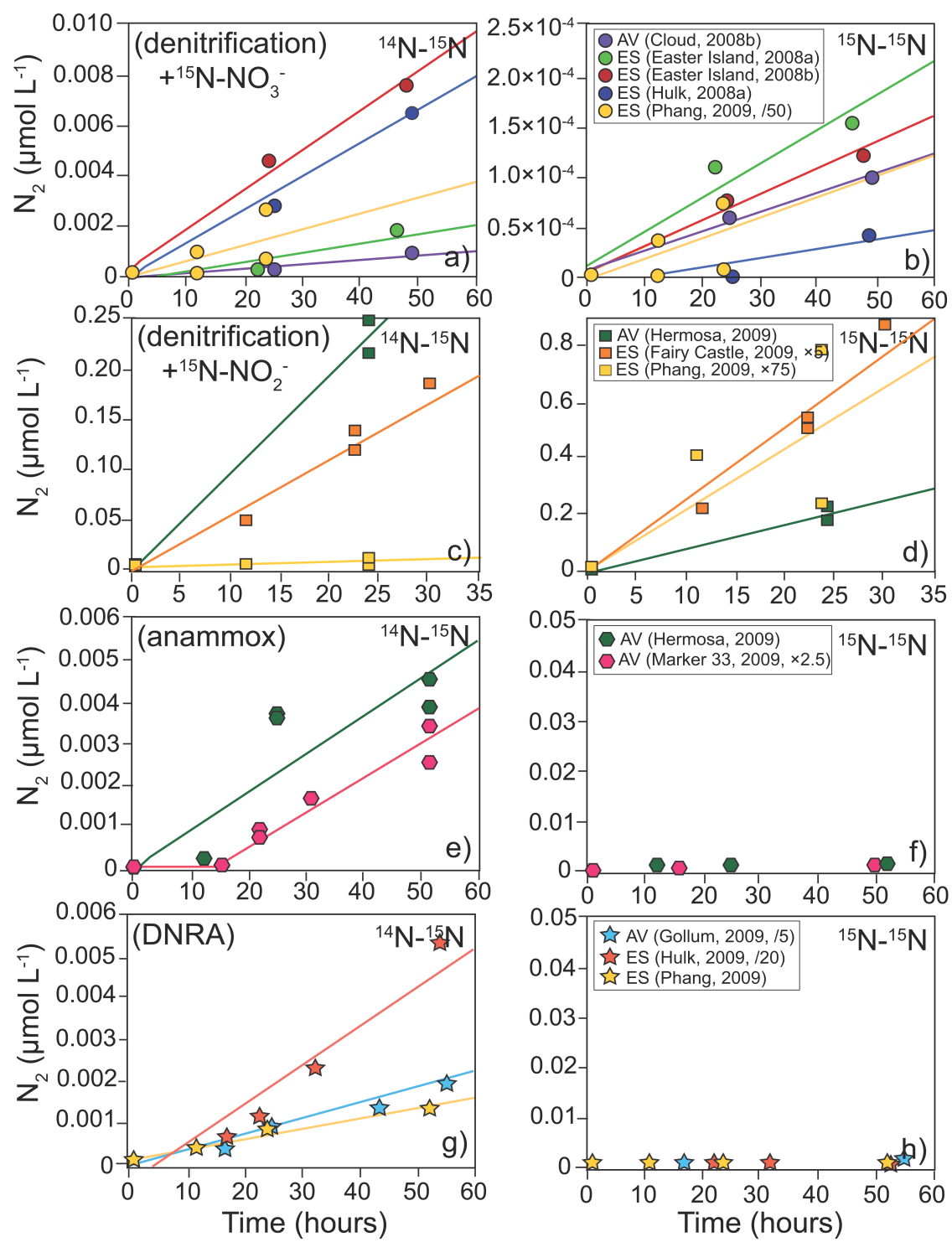

Fig. 2. Production of ${ }^{14,15} \mathrm{~N}_{2}$ and ${ }^{15,15} \mathrm{~N}_{2}$ over time for selected ${ }^{15} \mathrm{~N}$-labelled incubations: addition of ${ }^{15} \mathrm{NO}_{3}^{-}(\mathbf{a}, \mathbf{b}),{ }^{15} \mathrm{NO}_{2}^{-}(\mathbf{c}, \mathbf{d}),{ }^{15} \mathrm{NH}_{4}^{+}$ $(\mathbf{e}, \mathbf{f})$ and ${ }^{15} \mathrm{NO}_{3}^{-}$followed by the addition of hypobromite (see text for more detail) (g, h) to measure potential denitrification $(\mathbf{a}, \mathbf{b}, \mathbf{c}, \mathbf{d})$, anammox $(\mathbf{e}, \mathbf{f})$, and DNRA $(\mathbf{g}, \mathbf{h})$ rates in diffuse hydrothermal vent fluids. All $\mathrm{N}_{2}$ values were normalised to $0 \mu \mathrm{mol} 1^{-1}$ at time $t=0$. Values for duplicate measurements are shown for all 2009 incubations. Values at some sites were multiplied or divided (numbers next to vent names and sampling years in legends) to fit on the same scales.

replicates of a mixture made from $10 \mu \mathrm{mol} \mathrm{l}^{-1}$ of $\mathrm{Na}^{15} \mathrm{NO}_{3}$ and $10 \mu \mathrm{moll}^{-1}{ }^{14}\left(\mathrm{NH}_{4}\right)_{2} \mathrm{SO}_{4}$ were used as abiotic controls and were treated as samples. The exetainers were inverted to prevent any gas loss and samples were incubated overnight at room temperature. The production of ${ }^{29} \mathrm{~N}_{2}$ and ${ }^{30} \mathrm{~N}_{2}$ for all labelled experiments was then determined in the headspace through IRMS measurements as described above, and DNRA rates were calculated (from the production of ${ }^{29} \mathrm{~N}_{2}$ only). The calculated conversion factor, i.e., the fraction of $\mathrm{NH}_{4}^{+}$ converted to $\mathrm{N}_{2}$ from the abiotic controls, was close to $90 \%$ and data were corrected accordingly.

\subsection{Environmental DNA extraction and diversity profiling}

\subsubsection{DNA extraction}

Environmental DNA (eDNA) was extracted from $0.2 \mu \mathrm{m}$ Sterivex filters (Millipore) following the protocol described in Huber et al. (2002) with some modifications. $20 \mu \mathrm{l}$ of proteinase $\mathrm{K}\left(10 \mathrm{mg} \mathrm{ml}^{-1}\right)$ was added with the sodium dodecyl sulfate (SDS; $20 \%$ ) before incubation at $65^{\circ} \mathrm{C}$ for 2 hours, instead of at the beginning of the extraction together with extraction buffer. $200 \mu \mathrm{l}$ lysozyme $\left(50 \mathrm{mg} \mathrm{ml}^{-1}\right)$ was 
also added at this step. Finally, the eDNA was resuspended in $95 \mu \mathrm{l}$ of TE buffer (10 mm Tris, $1 \mathrm{~mm}$ EDTA, $\mathrm{pH} \mathrm{8.0)}$ and was stored at $-80^{\circ} \mathrm{C}$.

\subsubsection{PCR, cloning and sequencing}

Following dilutions of the original eDNA obtained from Cloud (AV, 2007), Bag City (AV, 2008), Hulk (ES, 2008b), Godzilla (ES) and Phang (ES) vents, near complete 16S rRNA genes were amplified using primers targeting the bacterial domain: B8F (5'-AGAGTTTGATCCTGGCTGAG$\left.3^{\prime}\right)$ and B1492R (5'-GGTTACCTTGTTACGACTT-3') under the following PCR conditions: $2 \mathrm{~min}$ at $94^{\circ} \mathrm{C}$, followed by 30 cycles of $94^{\circ} \mathrm{C}$ for $30 \mathrm{~s}, 55^{\circ} \mathrm{C}$ for $45 \mathrm{~s}, 72^{\circ} \mathrm{C}$ for $2 \mathrm{~min}$, and a final extension of $10 \mathrm{~min}$ at $72^{\circ} \mathrm{C}$. Each $20 \mu \mathrm{l}$ reaction contained $1 \mu \mathrm{l}$ of template DNA, $1 \mu \mathrm{l}$ of a $5 \mu \mathrm{mol} 1^{-1}$ forward and reverse primer, respectively, $2 \mu \mathrm{l}$ of $8 \mu \mathrm{moll}^{-1}$ deoxynucleotide solution, $1.25 \mu \mathrm{l}$ of a $50 \mu \mathrm{mol}^{-1}$ $\mathrm{MgCl}_{2}$ solution, $2.75 \mu \mathrm{l}$ of a $1 \times$ Invitrogen PCR Buffer, and $1 \mathrm{U}$ (unit) of Taq DNA polymerase (Bio-Rad). The PCR amplification products were visualised by UV excitation following electrophoresis on $\sim 1 \%$ (wt vol ${ }^{-1}$ ) agarose gels stained with SYBR safe (Invitrogen), reconditioned to eliminate heteroduplexes (Thompson et al., 2002) and purified using the QIAquick PCR Purification Kit according to the manufacturer's instructions. DNA was ligated into a $\mathrm{pCR}^{\circledR} 2.1 \mathrm{TOPO}^{\circledR}$ vector (Invitrogen) and transformed into chemically competent TOP $10 \mathrm{~F}^{\prime}$ One Shot ${ }^{\circledR}$ E. coli cells following the manufacturer's instructions. Transformants (white colonies) were randomly picked, grown in LB + Ampicillin, and cloned inserts were amplified with the vector primers M13F (5'-GTAAAACGACGGCCAG-3') and M13R (5'CAGGAAACAGCTATGAC- $3^{\prime}$ ) in a $50 \mu$ reaction mixture described in Forget et al. (2010). Inserts (218 in total, $\sim 30$ to 60 at each site) were sequenced at the High-Throughput Genomics Unit (University of Washington) or at the University of Victoria using the PCR primers B8F, B1492R, B515F (5'-GTGCCAGCMGCCGCGGTAA-3') and B907R (5'-CCGTCAATTCMTTTRAGTTT-3').

\subsubsection{Phylogenetic analysis}

All sequences were edited manually using Sequencher v.4.7 (Gene Codes Corporation). The open source Bellerophon application (http://comp-bio.anu.edu.au/bellerophon/ bellerophon.pl) (Huber et al., 2004) and PinTail (Ashelford et al., 2006) were used to detect chimeric sequences. Chimeras were excluded from further analysis. Nucleotide sequences (213 in total) were aligned using the ClustalW Application (Thompson et al., 1994) in BioEdit (version 7.0.5.3) and manually checked. Closest relatives were identified for each sequenced clone using BLAST (Altschul et al., 1990). Sequences were classified for phylogenetic analysis using the Ribosomal Database Project (RDP) Classifier tool (Wang et al., 2007). Maximum likelihood trees were inferred by PhyML (version 3.0 for Windows) (Guindon et al., 2010) using the HKY85 model of nucleotide evolution with 100 bootstrap replicates.

\subsubsection{Richness and diversity analysis}

Rarefaction curves were calculated using mothur version 1.22.2 (Shloss et al., 2009). Sequences with $<97 \%$ similarity were treated as distinct operational taxonomical units (OTU). OTU richness was calculated using the Chao-1 estimator (Chao, 1984). Diversity in the small subunit (SSU) rRNA clone libraries was determined using the Shannon index (H) (Krebs, 1999). The coverage for each clone library was calculated as in Ravenschlag et al. (1999) according to the formula:

$\mathrm{C}=\left[1-\left(n_{1} / N\right) \times 100\right]$

where $n_{1}$ is the number of different OTUs within the library and $N$ is the total number of clones sequenced. See Table 2 for 16S rRNA gene clone libraries information and OTUs richness (Chao-1) and diversity (Shannon) estimates.

\subsubsection{Sequences accession numbers}

Sequences were deposited to GenBank under the accession numbers JQ712372-JQ712487.

\subsection{Total bacterial cells and abundance of SUP05 and anammox bacteria}

Total cell abundances in diffuse hydrothermal fluids collected in 2008 and 2009 were determined by epifluorescence microscopy following DAPI staining in the laboratories of J. Holden (University of Massachusetts) and J. Baross (University of Washington). Total bacterial and SUP05 group specific SSU rRNA gene copy numbers were determined by qPCR using an Opticon ${ }^{\circledR} 2$ DNA Engine Real-Time PCR detection system (Bio-Rad) according to Zaikova et al. (2010). The following primer pairs were used for the quantification of Bacteria: 27F, (5'-AGAGTTTGATCCTGGCTCAG); DW519R (5'-GNTTTACCGCGGCKGCTG) and SUP05: Ba519F (5'-CAGCMGCCGCGGTAANWC-3') and 1048R, (5'-CCATCTCTGGAAAGTTCCGTCT-3').

We used the same standard as Zaikova et al. (2010) to quantify total and SUP05 bacteria with initial concentrations of $2.8 \times 10^{10}$ copies $\mu \mathrm{l}^{-1}$ and $8.5 \times 10^{8}$ copies $\mu^{-1}$, respectively, as determined from PicoGreen assays using the Quant-iT PicoGreen ${ }^{\circledR}$ dsDNA kit (Invitrogen). For all qPCR assays, calibration curves were constructed with six 10-fold dilutions of the standards. The limit of detection, set above the $\mathrm{Ct}$ (cycle threshold) values of the no-template controls, was generally less than $\sim 50$ copies $\mathrm{ml}^{-1}$ for total and SUP05 bacteria qPCR assays for all triplicate samples. The amplification efficiency for each run was estimated by the slope of the standard curve according to the equation: $E=\left(10^{-1 / \text { slope }}\right)$ and was in all cases above $95 \%$. 
Table 2. Bacterial 16S rRNA gene clone libraries information and OTUs richness (Chao-1) and diversity (Shannon) estimates. Sequences with a similarity $\geq 97 \%$ are considered the same OTU. Uncertainties for the Chao-1 estimator (in brackets) and the Shannon index represents $95 \%$ confidence intervals.

\begin{tabular}{|c|c|c|c|c|c|c|c|c|c|}
\hline $\begin{array}{l}\text { Vent } \\
\text { field }\end{array}$ & Site & Year & $\begin{array}{l}\text { Volume of } \\
\text { fluid filtered }(\mathrm{L})\end{array}$ & $\begin{array}{l}\text { Average fluid } \\
\text { temp. }\left({ }^{\circ} \mathrm{C}\right)\end{array}$ & $\begin{array}{l}\text { \# of clones } \\
\text { sequenced }\end{array}$ & $\begin{array}{l}\text { \# of } \\
\text { OTU }\end{array}$ & $\begin{array}{c}\text { Coverage } \\
(\%)\end{array}$ & $\begin{array}{r}\text { Chao-1 } \\
\text { estimator }\end{array}$ & $\begin{array}{r}\text { Shannon } \\
\text { index }\left(\mathrm{H}^{\prime}\right)\end{array}$ \\
\hline AV & Cloud & 2007 & 3.0 & 6.8 & 60 & 39 & 50 & $\begin{array}{r}133 \\
(74-295)\end{array}$ & $3.47 \pm 0.43$ \\
\hline AV & Bag City & 2008 & 1.6 & 11.2 & 43 & 26 & 63 & $\begin{array}{r}43 \\
(31-82)\end{array}$ & $3.09 \pm 0.25$ \\
\hline ES & Godzilla & 2008 & 4.0 & 29 & 28 & 19 & 50 & $\begin{array}{r}67 \\
(37-179)\end{array}$ & $2.95 \pm 0.29$ \\
\hline ES & Hulk & 2008 & 4.0 & 24.8 & 60 & 18 & 77 & $\begin{array}{r}60 \\
(31-161)\end{array}$ & $1.72 \pm 0.43$ \\
\hline ES & Phang & 2009 & 2.7 & 24 & 27 & 19 & 56 & $\begin{array}{r}34 \\
(25-67)\end{array}$ & $2.94 \pm 0.27$ \\
\hline
\end{tabular}

We also assessed anammox bacterial abundances using a qPCR approach following the method described in Humbert et al. (2012). Standard curves were prepared by serial dilution of a plasmid preparation of an anammox clone from Lake Lugano, Switzerland (Wenk et al., 2013). All samples and standards were run in triplicates on a Rotor-gene ${ }^{\mathrm{TM}}$ 3000 Real-Time PCR detection system (Corbett Research). No anammox bacteria were detected in any of the samples from this study, while anammox-bacteria amended control samples yielded positive results (data not shown).

\section{Results}

\subsection{Physico-chemical properties}

Temperature, $\mathrm{pH}$ and $\mathrm{Mg}^{2+}, \mathrm{N}_{2} \mathrm{O}, \mathrm{H}_{2} \mathrm{~S}, \mathrm{PO}_{4}^{3-}, \mathrm{NO}_{3}^{-}$and $\mathrm{NH}_{4}^{+}$concentrations are summarised in Table 1 for all low-T vent fluids sampled at Axial Volcano and Endeavour Segment. Diffuse fluid temperatures ranged from $7^{\circ} \mathrm{C}$ (Cloud, AV) to $37^{\circ} \mathrm{C}$ (Hermosa, AV) and $\mathrm{pH}$ varied between $\sim 5.5$ and 7.0. Magnesium concentrations ranged between 42 and $53 \mathrm{mmol} \mathrm{kg}^{-1}$, and were generally close to the $\left[\mathrm{Mg}^{2+}\right]$ for background seawater $\left(53 \mathrm{mmol} \mathrm{kg}{ }^{-1}\right)$. Magnesium is almost completely removed from aqueous solution during high-T hydrothermal circulation through various water-rock reactions, and resupplied during mixing with crustal seawater at lower temperatures (Edmond et al., 1979). As a result, a clear linear relationship exists between temperature and $\left[\mathrm{Mg}^{2+}\right]$ (Butterfield et al., 2004; Bourbonnais et al., 2012), and $\left[\mathrm{Mg}^{2+}\right]$ can thus be used as a proxy for the degree of mixing in the hydrothermal vent fluids. Nitrous oxide concentrations ranged between $\sim 0$ (not detectable after blank correction) and $347 \mathrm{nmoll}^{-1}$, similar to previous observations at Axial Volcano (Butterfield et al., 2004). Hydrogen sulfide concentrations were generally high (up to $1300 \mathrm{~mol}^{-1}$ at Marker 113, AV). Phosphate concentrations varied from 1.5 to $4 \mu \mathrm{moll}^{-1}$ (compared to $\sim 3 \mu \mathrm{moll}^{-1}$ in background seawater). Nitrate concentrations ranged from $1.6 \mu \mathrm{moll}^{-1}$ (Marker 113, AV, 2007) to $41.7 \mu \mathrm{mol}^{-1}$ (Hermosa, AV) and were generally lower than background deep-sea water $\left(\sim 40-42 \mu \mathrm{mol} \mathrm{l}^{-1}\right)$. Nitrite concentrations were low, accounting for generally less than $2 \%$ (data not shown in Table 1) of total $\mathrm{NO}_{\mathrm{x}}$.

Ammonium concentrations were generally low $\left(<4 \mu \mathrm{moll}^{-1}\right.$ at most sites) at Axial Volcano, compared to Endeavour Segment where $\left[\mathrm{NH}_{4}^{+}\right]$was between $15 \mu \mathrm{mol}^{-1}$ and $56 \mu \mathrm{mol} 1^{-1}$. Lower $\mathrm{NH}_{4}^{+}$concentrations (1 to $4 \mu \mathrm{mol}^{-1}$ ) were observed in the ROPOS suction samples from the June 2008 cruise and are likely the result of dilution by entrainement of surrounding seawater during sampling with this less efficient device (versus the dedicated vent fluid sampler) rather than reflecting actual in situ concentrations. In an attempt to estimate the net consumption or production of fixed $\mathrm{N}$ (i.e., $\mathrm{NO}_{3}^{-}$and $\mathrm{NH}_{4}^{+}$) in diffuse hydrothermal vent fluids, we calculated $\mathrm{NO}_{3}^{-}, \mathrm{NH}_{4}^{+}$and DIN deficits, according to the following equations that take water mixing into account:

$$
\begin{aligned}
& \mathrm{NO}_{3 \text { deficit }}^{-}=\left[\left(\left[\mathrm{Mg}^{2+}\right]_{\text {meas }} /\left[\mathrm{Mg}^{2+}\right]_{\mathrm{sw}}\right) \times\left[\mathrm{NO}_{3}^{-}\right]_{\mathrm{sw}}\right]-\left[\mathrm{NO}_{3}^{-}\right]_{\text {meas }} \\
& \mathrm{NH}_{4 \text { deficit }}^{+}=\left[\left(1-\left[\mathrm{Mg}^{2+}\right]_{\text {meas }} /\left[\mathrm{Mg}^{2+}\right]_{\text {sw }}\right) \times\left[\mathrm{NH}_{4}^{+}\right]_{\text {high-T }}\right]-\left[\mathrm{NH}_{4}^{+}\right]_{\text {meas }} \\
& \mathrm{DIN}_{\text {deficit }}=\mathrm{NO}_{3 \text { deficit }}^{-}+\mathrm{NH}_{4 \text { deficit }}^{+}
\end{aligned}
$$

where $\left[\mathrm{NO}_{3}^{-}\right]_{\text {meas }},\left[\mathrm{NH}_{4}^{+}\right]_{\text {meas }}$, and $\left[\mathrm{Mg}^{2+}\right]_{\text {meas }}$ are $\mathrm{NO}_{3}^{-}$, $\mathrm{NH}_{4}^{+}$and $\mathrm{Mg}^{2+}$ concentrations measured in diffuse fluids, respectively, $\left[\mathrm{NO}_{3}^{-}\right]_{\mathrm{sw}}$ and $\left[\mathrm{Mg}^{2+}\right]_{\mathrm{sw}}$ are $\mathrm{NO}_{3}^{-}$and $\mathrm{Mg}^{2+}$ concentrations in background seawater collected near $\mathrm{AV}$ and $\mathrm{ES}$, and $\left[\mathrm{NH}_{4}^{+}\right]_{\text {high-T }}$ is the $\mathrm{NH}_{4}^{+}$concentration in the high-T end-member. $\left[\mathrm{NO}_{3}^{-}\right]_{\mathrm{sw}}$ is constant at $\sim 40 \mu \mathrm{mol}^{-1}$ and the average $\mathrm{NH}_{4}^{+}$concentrations in high- $\mathrm{T}$ vent fluids varies between vent fields: $14 \mu \mathrm{moll}^{-1}$ (AV), $396 \mu \mathrm{mol} 1^{-1}$ (ES, M), $410 \mu \mathrm{moll}^{-1}$ (ES, ME), $863 \mu \mathrm{mol} \mathrm{l}^{-1}$ (ES, HR) (data from Bourbonnais et al., 2012). Nitrate, $\mathrm{NH}_{4}^{+}$and DIN deficits ranged from $38 \mu \mathrm{moll}^{-1}$ (Marker 113, AV, 2007) to $-2 \mu \mathrm{moll}^{-1}$ (Hermosa, AV), from $16 \mu \mathrm{moll}^{-1}$ (Fairy Castle, 
ES) to $-12 \mu \mathrm{moll}^{-1}$ (Marker 113, AV, 2007) and $30 \mu \mathrm{mol} \mathrm{l}^{-1}$ (Bag City, AV) to $-3 \mu \mathrm{moll}^{-1}$ (Hermosa, AV), respectively (Table 1) (with negative values indicating a surplus).

\subsection{Potential rates of denitrification, anammox and DNRA}

Production of ${ }^{29} \mathrm{~N}_{2}$ and ${ }^{30} \mathrm{~N}_{2}$ during ex situ incubations generally showed linear behaviour during the incubation period (Fig. 2). Nitrate concentration changes in the incubations (not shown) were generally qualitatively consistent with observed $\mathrm{N}_{2}$ production trends. Even at sites where we measured the lowest denitrification rate of $0.5 \mathrm{nmoll}^{-1} \mathrm{day}^{-1}$ (Easter Island, ES, 2008b), the associated $\delta^{29} \mathrm{~N}_{2}$ and $\delta^{30} \mathrm{~N}_{2}$ increases (1.3\% and $9.0 \%$, respectively) were well within the average precision of the measurements (see Sect. 2.3), so that we can state that the rate detection limit is $<0.5 \mathrm{nmol}^{-1}$ day $^{-1}$. Parallel incubations of 2009 samples with addition of either ${ }^{15} \mathrm{~N}$-labelled $\mathrm{NO}_{3}^{-}$or $\mathrm{NO}_{2}^{-}$generally yielded similar denitrification and DNRA rates, usually with less than $30 \%$ variation between the two series of incubations. Average rates for both series of incubations (2009 samples) are indicated in Fig. 3 when production of ${ }^{29} \mathrm{~N}_{2}$ and ${ }^{30} \mathrm{~N}_{2}$ was linear.

Denitrification rates in diffuse vent fluids varied strongly between sites, ranging from $0.5 \mathrm{nmolNl}^{-1} \mathrm{day}^{-1}$ (Easter Island, ES, 2008b) to $977 \mathrm{nmol} \mathrm{N}^{-1}$ day $^{-1}$ (Hermosa, AV) (Fig. 3). Some temporal variability was observed at sites sampled multiple times. For example, measured denitrification rates ranged from $2 \mathrm{nmol} \mathrm{N1}^{-1} \mathrm{day}^{-1}$ (2008a) to $577 \mathrm{nmol} \mathrm{N}^{-1} \mathrm{day}^{-1}$ (2009) at Hulk (ES) and from $83 \mathrm{nmol} \mathrm{N}^{-1}$ day $^{-1}$ (2008b) to $251 \mathrm{nmol} \mathrm{N}^{-1}$ day $^{-1}$ (2009) at Marker 113 (AV). Denitrification rates were always relatively low at Easter Island, ES (i.e. $8 \mathrm{nmol} \mathrm{N}^{-1}$ day $^{-1}$, 2008a; and $0.5 \mathrm{nmol} \mathrm{N}^{-1} \mathrm{day}^{-1}$, 2008b). No significant differences were found between denitrification rates at Axial Volcano and Endeavour Segment for all samples collected during the 2008 and 2009 cruises or during individual cruises (Mann-Whitney test for non-parametric data, $95 \%$ confidence limit).

Anammox rates in vent fluids were below $5 \mathrm{nmol} \mathrm{N}^{-1} \mathrm{day}^{-1}$ at Hermosa (AV), Marker 113 (AV) and Phang (ES) and below the detection limit (BDL) for the two other sites (Marker 113, AV and Fairy Castle, ES). DNRA rates ranged from BDL at Marker 33 (AV) and Fairy Castle (ES) to $152 \mathrm{nmol} \mathrm{N1}^{-1} \mathrm{day}^{-1}$ (Hulk, ES) (Fig. 3). There was no significant difference in DNRA rates between Axial Volcano and Endeavour Segment (Mann-Whitney test, $95 \%$ confidence limit).

\subsection{Composition of 16S rRNA gene clone libraries and abundance of SUP05 bacteria}

Bacterial diversity in diffuse vent fluids was generally high (Shannon index $\geq 2.9$ ) except at Hulk, ES (Shannon index of
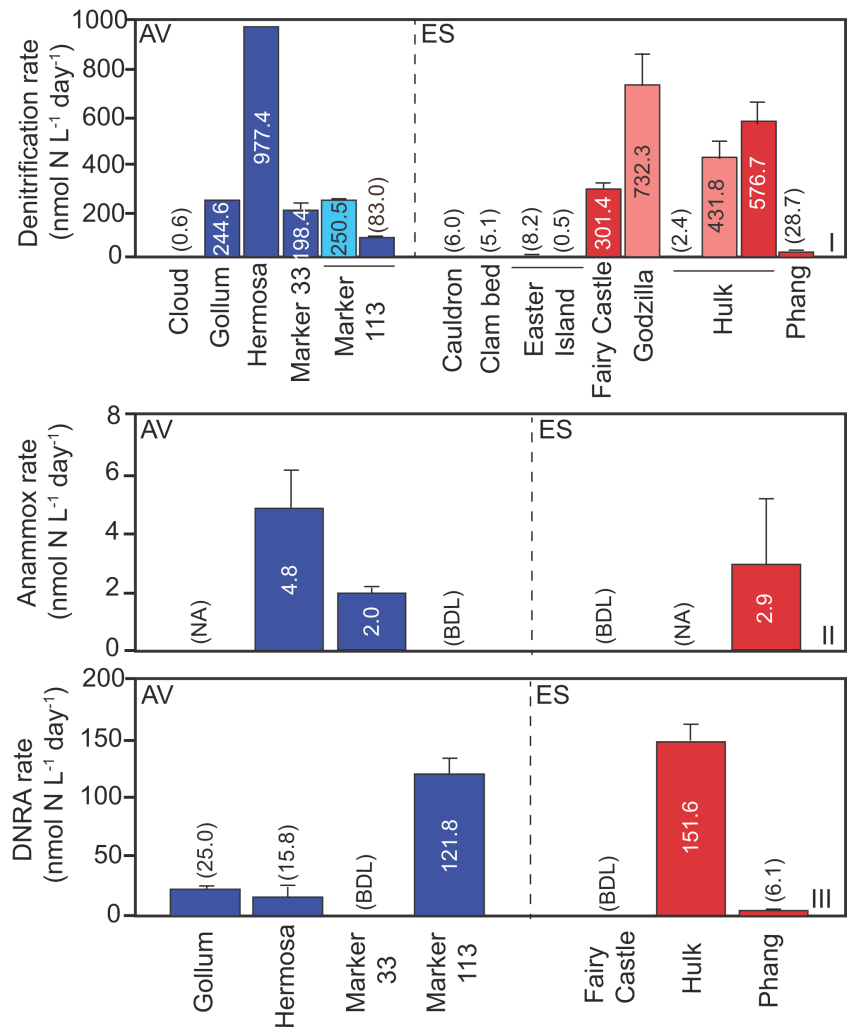

Fig. 3. Denitrification (I), anammox (II) and DNRA (III) rates in nmol N $1^{-1}$ day $^{-1}$ at Endeavour Segment (ES) and Axial Volcano (AV) on the Juan de Fuca Ridge. The average denitrification and DNRA rates obtained from both ${ }^{15} \mathrm{NO}_{3}^{-}$and ${ }^{15} \mathrm{NO}_{2}^{-}$-labelled incubations during the 2009 cruise are shown when linear relationships were obtained (i.e., at Marker 113, Marker 33, Fairy Castle, Phang and Hulk). Note the different scales for the y-axis. Numbers inside bars or in brackets are actual values. Colour of the bar represents the sampled vent field (i.e., AV=blue and $\mathrm{ES}=$ red) and colour intensity (i.e., no colour, medium and dark) represents sites sampled during the June 2008 (always low rates, i.e., Clam bed, Easter Island and Hulk, first bars), August-September 2008 and June 2009 cruises, respectively. Vertical lines represent the error propagation of the standard errors of the slopes of the linear relationships represented in Fig. 2 (i.e., ${ }^{14,15} \mathrm{~N}_{2}$ and/or ${ }^{15,15} \mathrm{~N}_{2}$ versus time).

1.7) (Table 2). 16S rRNA gene clone libraries derived from Cloud (AV), Bag City (AV), Godzilla (ES) and Phang (ES) were dominated by $\varepsilon$-proteobacteria (up to $\sim 80 \%$ of total clones sequenced at Bag City, AV). The dominant genera of $\varepsilon$-proteobacteria were, in order of abundance, Sulfurovum (up to $56 \%$ of total clones at Godzilla, ES), Sulfurimonas (up to $19 \%$ of total clones at Bag City, AV), Arcobacter (up to $23 \%$ of total clones at Bag City, AV) and Nitratifractor (up to $7 \%$ of total clones at Phang, ES) (Fig. 4). Figure S1 presents a partial $16 \mathrm{~S}$ rRNA gene $\varepsilon$-proteobacteria tree showing phylogenetic relationships for all 16S rRNA gene sequences in these four major $\varepsilon$-proteobacteria genera. 


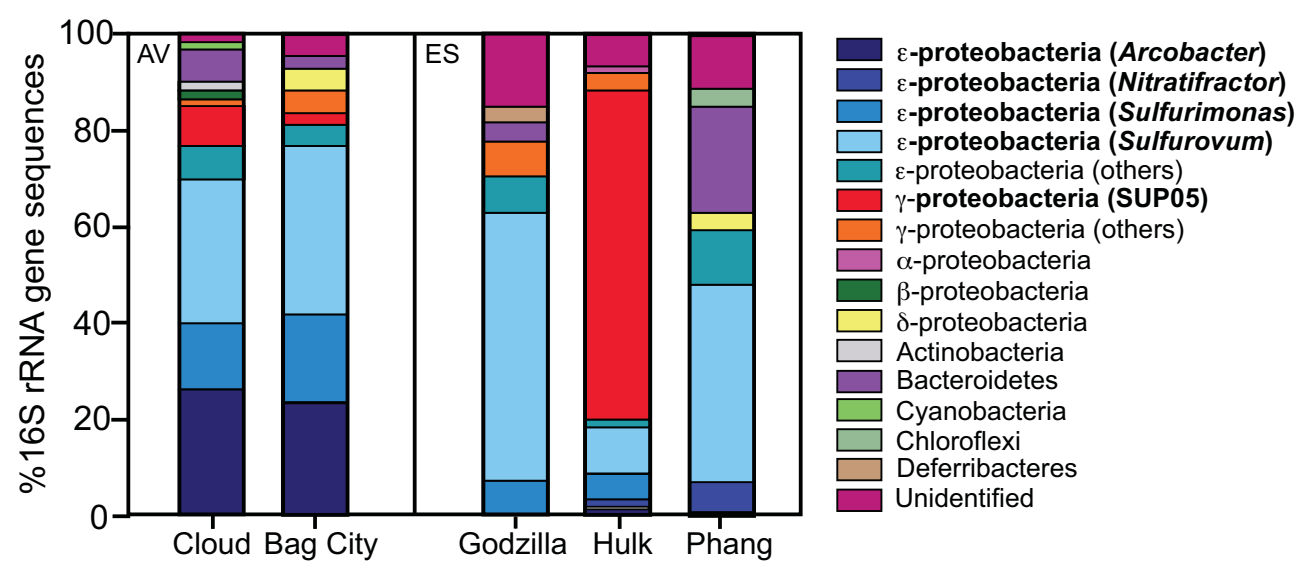

Fig. 4. Composition of the 16S rRNA gene clone libraries recovered from DNA extracted from 5 DNA samples from diffuse vent fluids at Axial Volcano (AV) and the Endeavour Segment (ES) on the Juan de Fuca Ridge: Cloud (AV07-CP), Bag City (AV08-BC), Hulk (ES08-H), Godzilla (ES08-G) and Phang (ES09-P) (see Table 2). SUP05 and other potential $\mathrm{NO}_{3}^{-}$reducing bacteria are in bold. Note that only a limited number of clones were sequenced at each site. See Table 2 for more information about DNA samples and 16S rRNA gene clone libraries.

In contrast, the $16 \mathrm{~S}$ rRNA clone library derived from the Hulk (ES) site showed a dominance of $\gamma$-proteobacteria, accounting for up to $77 \%$ of the sequences (Fig. 4). Sequences affiliated with SUP05 were generally the most prevalent $\gamma$-proteobacteria, accounting for up to $68 \%$ of the total 16S rRNA gene clone library at Hulk, ES (Fig. 4). The abundance of SUP05 bacteria (relative to total bacteria) measured by qPCR was up to $38 \%$ at this site. At all other sites, the relative abundance of SUP05 bacteria was generally lower than 4\%, except at Cloud (AV, 2007; 26\%), Marker 33 (AV, 2008; 7.9\%) and Bag City (AV, 2008; $5.4 \%$ ) (Fig. 5, Table S1). At Cloud (AV), Bag City (AV) and Hulk (ES), $\gamma$-proteobacteria of the SUP05 sequences were most similar to hydrothermal vent bacteria from an iron chimney-like structure on Volcano 19 in the South Pacific Ocean (99\%) (Forget et al., 2010), and to water column bacteria from Saanich Inlet, a seasonally anoxic fjord (e.g., clone FGYC_49P14 and clone SHBH489), corresponding to phylotype SI-1 identified by Walsh et al. (2009). No $\gamma$-proteobacteria from the Arctic96BD-19 clade (see Bano and Hollibaugh, 2002) were detected in our samples (Fig. 6).

\subsection{Relation between denitrifying bacteria activity and abundance, as well as environmental factors}

Relationships between potential activities and abundance of denitrifying, anammox and DNRA bacteria (ex situ rates) as well as environmental physico-chemical factors (e.g., temperature, $\mathrm{pH}, \mathrm{PO}_{4}^{3-}, \mathrm{H}_{2} \mathrm{~S}$ and $\mathrm{N}_{2} \mathrm{O}$ concentrations) were evaluated using multiple Spearman's rank order correlations for non-parametric data. Since denitrification rates were not significantly different between the two sampled ridge segments (i.e., Axial Volcano and Endeavour Segment), we pooled data from all vent fields and years for our analysis. Significant negative relationships were observed between denitrification rate and the in situ $\mathrm{NO}_{3}^{-}$

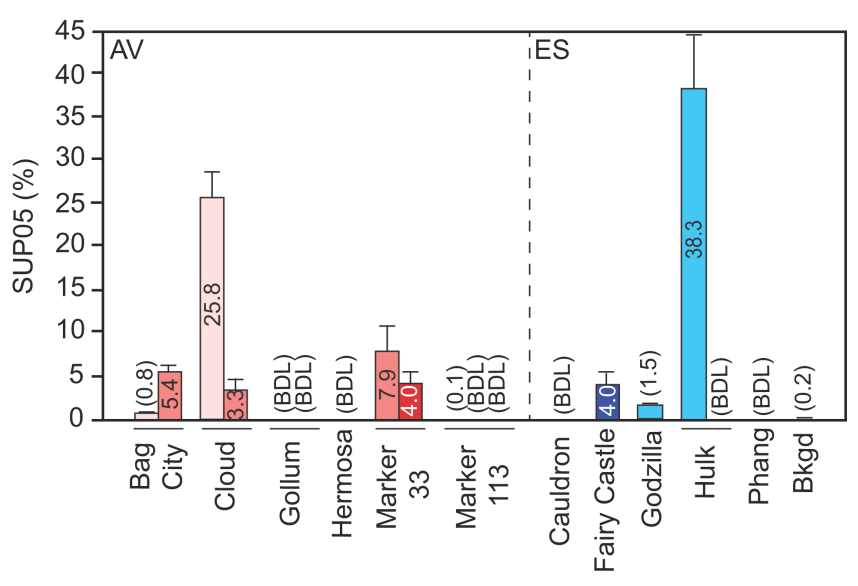

Fig. 5. SUP05 relative abundance (in $\%$, relative to $16 \mathrm{~S}$ rRNA gene copy number $\mathrm{ml}^{-1}$ seawater) at Axial Vocano (AV) and the Endeavour Segment (ES) on the Juan de Fuca Ridge. Same colour scheme as in Fig. 3 (paler colours represent samples from the 2007 cruise). Actual values are indicated inside the bars or within parentheses. Bkgd is a background sample that was collected near the Endeavour Segment in 2009. See Table 1 for chemico-physical properties of sampled sites. Copy numbers per ml seawater of bacterial 16S rRNA genes (for both total and SUP05 bacteria) are available as Supplement Materials, Table S1.

deficit (Spearman's $\rho=-0.55$, p-value $=0.05, n=13$ ), and between the anammox rate and the total DIN deficit (Spearman's $\rho=-0.95$, p-value $=0.01, n=5$ ) (Fig. 7), although sample size was limited for the latter dataset. It should be noted that since we added the same amount of ${ }^{15} \mathrm{~N}$-labelled $\mathrm{NO}_{3}^{-}$in all incubations performed during the same year, the degree of correlation (and significance) observed between total $\mathrm{NO}_{3}^{-}$(including ${ }^{15} \mathrm{~N}$-labelled $\mathrm{NO}_{3}^{-}$ added before the incubations) and denitrification rates was similar (Spearman's $\rho=-0.68$, p-value $=0.01, n=13$ ). 


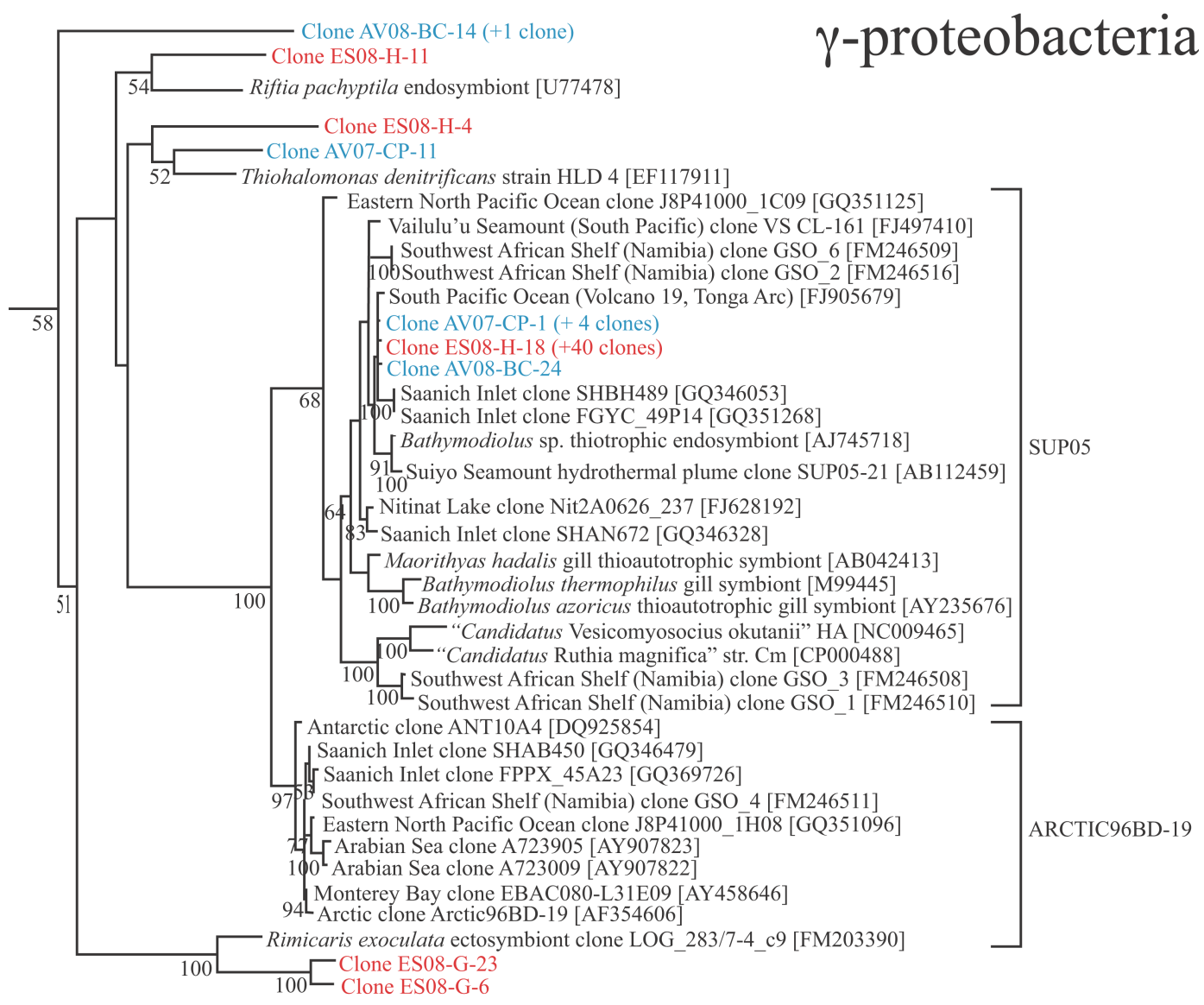

$0.1 \mathrm{sub} / \mathrm{site}$

Fig. 6. Partial 16S rRNA gene $\gamma$-proteobacteria phylogenetic tree constructed using the maximum likelihood method implemented in PHYML. Clone prefixes were assigned as follows: the first letters indicate the vent fields: $\mathrm{AV}=\mathrm{Axial}$ Volcano (in blue) and ES $=$ Endeavour Segment (in red), followed by the year $(07=2007$ and $08=2008)$ and the last letters the diffuse vent sampled: $\mathrm{CP}=\mathrm{Cloud}$ Pit, $\mathrm{BC}=\mathrm{Bag} \mathrm{City}$, $\mathrm{H}=\mathrm{Hulk}$, and $\mathrm{G}=$ Godzilla. The last numbers indicate clones \#. The number of clones that are $\geq 97 \%$ identical to a given hydrothermal vent clone is indicated in parentheses. GenBank accession numbers are provided (in brackets) for all other clones not sequenced in this study. The percentage of 100 bootstrap resamplings above $50 \%$ is indicated. The scale bar indicates the number of amino acid substitutions per site.
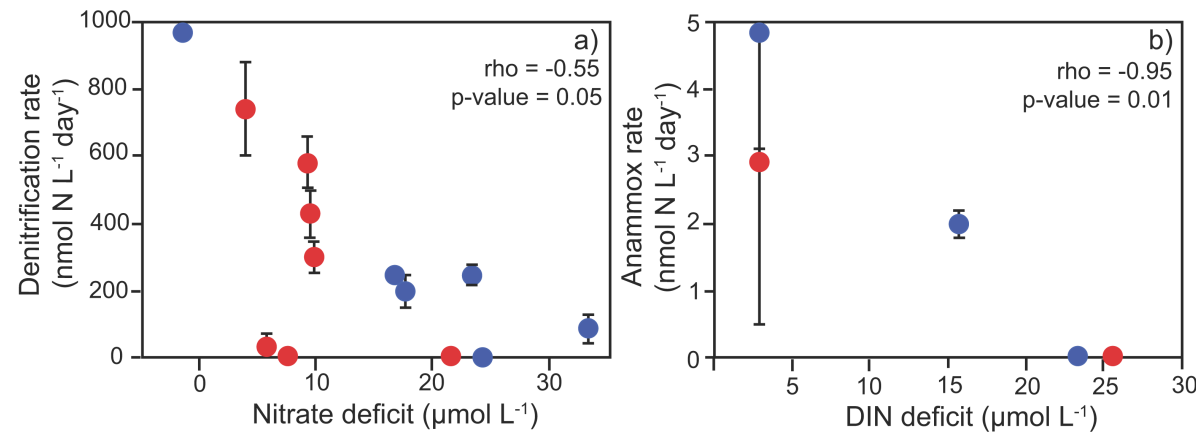

Fig. 7. Relationships between potential denitrification rate and $\mathrm{NO}_{3}^{-}$deficit (a), and potential anammox rate and total DIN deficit (b) in hydrothermal vent fluids of the Juan de Fuca Ridge. See text for details. Hydrothermal vent fluids sampled from Axial Volcano and the Endeavour Segment are indicated in blue and red, respectively. Spearman's rank correlation coefficient $(\rho)$ and p-value are shown. Reported errors for denitrification and anammox rates were derived from standard errors of the regression coefficients. 


\section{Discussion}

\subsection{Denitrification as dominant $\mathrm{N}$ sink in diffuse vent fluids}

Our results suggest that denitrification is by far the dominant $\mathrm{N}$ loss process in the subsurface hydrothermal biosphere of the Juan de Fuca Ridge (Fig. 3). Denitrification rates in discharging hydrothermal fluids were up to $\sim 500$ times higher than anammox rates and up to 160 times higher than DNRA rates. It is interesting to note that unusually high $\mathrm{NH}_{4}^{+}$ concentrations (up to $\sim 13 \mu \mathrm{mol}^{-1}$ ), possibly produced during DNRA, were observed at Marker 113 (AV) in 2007, 2008 and 2009. The rates presented here are potential ex situ rates (measured at in situ temperatures), without accounting for possible pressure effects. Devol et al. (2006) reported no significant differences in denitrification rates measured in situ and ex situ for samples from the Arabian Sea oxygen deficient zone, at a depth range of 150 to $300 \mathrm{~m}$. While barophilic bacteria from great depths in the ocean are known to have pressure-dependent metabolic and growth rates (reviewed by Yayanos, 1995), there is currently no evidence to suggest that bacteria from the depths encountered here $(1500$ to $2200 \mathrm{~m})$ should have different metabolisms at sea surface pressures. Nonetheless, future studies should investigate the potential effects of pressure on microbial metabolism at these depths.

At some sites, $\mathrm{N}_{2}$ production by denitrification was significantly higher than what is generally observed for other open ocean and coastal oxygen-deficient zones. For example, denitrification rates ranged from 9.1 (open ocean) to 33.2 (coastal) nmol N1 ${ }^{-1} \mathrm{day}^{-1}$ in the Arabian Sea (Devol et al., 2006). Our higher rates were similar to rates reported by Lavik et al. (2009) for chemolithoautotrophic denitrification coupled to sulfide oxidation in the Namibian shelf waters (i.e., $\sim 600 \mathrm{nmol} \mathrm{N}^{-1}$ day $^{-1}$ ) and by Manning et al. (2010) in Saanich Inlet, a highly productive British Columbia (Canada) fjord (up to $\sim 200 \mathrm{nmol} \mathrm{N}^{-1} \mathrm{day}^{-1}$ ). From a hydrochemical point of view, cold seeps are environments that are very similar to hydrothermal vents, albeit with lower discharge rates, since they contain high concentrations of reducing substances such as $\mathrm{H}_{2} \mathrm{~S}$ and $\mathrm{CH}_{4}$. Bowles and Joye (2011) recently reported heterotrophic denitrification rates of up to $32 \mu \mathrm{molN} l^{-1} \mathrm{day}^{-1}$, in surficial cold seep sediments with Beggiatoa sp. mats in the Gulf of Mexico, suggesting that $\mathrm{N}$ loss via denitrifying bacteria (whether autotrophic or heterotrophic) could be an important process in both of these deep-sea reducing environments.

Although complete denitrification is almost certainly dominant, we note that estimates of total $\mathrm{NO}_{3}^{-}$conversion to gaseous products reported here may be conservative underestimates as we only measured $\mathrm{N}_{2}$ and not $\mathrm{N}_{2} \mathrm{O}$ production. Measured $\left[\mathrm{N}_{2} \mathrm{O}\right]$ in sampled fluids was as high as $347 \mathrm{nmoll}^{-1}$ (Fairy Castle, ES). Some denitrifiers, including sulfur-oxidizing bacteria, lack the gene coding for $\mathrm{N}_{2} \mathrm{O}$ reductase (nosZ), so that the final product of denitrification is $\mathrm{N}_{2} \mathrm{O}$. In particular, the nos $Z$ gene was not found in the metagenome of the SUP05 bacteria (Walsh et al., 2009), suggesting that their energy metabolism can result in net $\mathrm{N}_{2} \mathrm{O}$ production. $\mathrm{N}_{2} \mathrm{O}$ is also produced during nitrification (Betlach and Tiedje, 1981), which can occur in subsurface hydrotheral conduit systems as a result of the discontinuous mixing of anoxic hydrothermal fluids and oxic seawater. Indeed, Wang et al. (2009) reported the presence of bacterial and archaeal amoA (ammonia monooxygenase) genes required for nitrification in hydrothermal vent chimneys of the Juan de Fuca Ridge. This additional process confounds any attempt to estimate the relative proportion of $\mathrm{N}_{2} \mathrm{O}$ produced during denitrification only. Also, $\mathrm{N}_{2}$ production at the microbial community level should be seen as the definitive end product of $\mathrm{N}$ loss, whereas $\mathrm{N}_{2} \mathrm{O}$ produced by distinct groups of denitrifiers could be further reduced to $\mathrm{N}_{2}$ by other groups of bacteria.

Potential anammox rates were relatively low $\left(<5 \mathrm{nmol} \mathrm{N}^{-1} \mathrm{day}^{-1}\right.$, Hermosa, AV) in diffuse fluids, compared to denitrification. In fact, we rarely observed any $\mathrm{NH}_{4}^{+}$deficits in diffuse fluids, but rather a surplus of $\mathrm{NH}_{4}^{+}$with respect to $\mathrm{NH}_{4}^{+}$concentrations expected for conservative mixing (Table 1). This, in fact, supports net $\mathrm{NH}_{4}^{+}$production, rather than consumption by anammox. For comparison, Byrne et al. (2009) measured potential anammox rates of up to $60 \mathrm{nmolNl}^{-1} \mathrm{day}^{-1}$ in an aqueous mixture of hydrothermal vent chimneys from the Mid-Atlantic Ridge. Their rates are higher than ours possibly because of the increased microbial population density of their aqueous mixture compared to diffuse hydrothermal fluids. Our low to undetectable anammox rates agree with our microbiological results (see Sect. 4.2).

As observed in previous studies in other sulfidic marine environments (e.g., Lavik et al., 2009), our results indicate that during $\mathrm{N}_{2}$ production, fast growing denitrifying bacteria (doubling time as short as $\sim 1.5$ hour for sulfide-oxidizing autotrophic denitrifiers, Sievert et al., 2008) generally out-compete slow-growing anammox bacteria (doubling times of $\sim 2$ weeks, Strous et al., 1999) for $\mathrm{NO}_{\mathrm{x}}$ in diffuse fluids. Also, it has been suggested that fluctuating oxic-anoxic conditions could favour the more metabolically versatile denitrifying bacteria over anammox bacteria. Indeed, many denitrifiers can survive for extended periods of time in the absence of $\mathrm{NO}_{\mathrm{x}}$ (Risgaard-Petersen et al., 2005) and perform aerobic respiration or use other electron acceptors (e.g., Fe), and this may confer them a competitive advantage over anammox bacteria in environments with variable redox conditions.

\subsection{Denitrifier community in the subsurface biosphere}

Denitrifying bacteria have been reported to belong to diverse phylogenetic groups (Zumft, 1997). The capacity for autotrophic denitrification has been documented for $\alpha-, \beta-$, 
$\gamma$-, and $\varepsilon$-proteobacteria in a wide range of environments (e.g., hydrothermal vents, deep-sea redox transition zones, sediments, soils and inland soda lakes; review by Shao et al., 2010). Denitrification capacity has also been identified in extremophile Archaea (see review by Cabello et al., 2004). Archaea only constituted a small component of the total microbial community associated with the vent fluids sampled in this study (qPCR archaeal abundance up to $6 \%$ at Cauldron, ES - data not shown) and in a survey of diffuse hydrothermal fluids from Mariana Arc seamounts (typically less than 3\%; Huber et al., 2010). Therefore, archaeal denitrification was not further addressed.

Chemolithoautotrophic $\varepsilon$-proteobacteria have been identified as the dominant species in different hydrothermal habitats such as water column plumes, discharging fluids (i.e., subsurface) and living in symbioses with vent animals, using both culture and molecular approaches (López-García et al., 2003; Alain et al., 2004; Nakagawa et al., 2005a; Huber et al., 2010). Culture experiments by Nakagawa et al. (2005a) showed that $\varepsilon$-proteobacteria strains isolated from hydrothermal vent fluids, colonisation devices and annelid polychaete tubes at the Iheya North hydrothermal field in the Okinawa Trough were able to couple $\mathrm{H}_{2}, \mathrm{~S}_{2} \mathrm{O}_{3}^{2-}$ and $\mathrm{S}^{0}$ oxidation with $\mathrm{O}_{2}$ or $\mathrm{NO}_{3}^{-}$reduction, illustrating the versatility of bacterial metabolisms in these environments. In addition, the same authors showed that some isolates preferentially used $\mathrm{NO}_{3}^{-}$as an electron acceptor during sulfide oxidation, even in the presence of oxygen. These autotrophic denitrifying $\varepsilon$-proteobacteria included members of the genera Sulfurimonas (comprising Sulfurimonas paralvinellae sp. Takai et al., 2006), Sulfurovum (comprising Sulfurovum sp. NBC37-1; Inagaki et al., 2004) and Nitratifractor (i.e., Nitratifractor Salsuginis Nakagawa et al., 2005b). Additionally, Sievert et al. (2008) and Grote et al. (2012) reported that other $\varepsilon$-proteobacteria of the genus Sulfurimonas (Sulfurimonas denitrificans str. DMS1251 and Sulfurimonas gotlandica str. GD1) isolated from marine environments can perform both chemolithoautotrophic denitrification (coupled to sulfur oxidation) and heterotrophic denitrification. All of the above-mentioned $\varepsilon$-proteobacteria genera, plus the genus Arcobacter, were generally present in hydrothermal vent fluids in this study (Fig. 4 and S1) and represented up to $77 \%$ (Bag City, AV) of the 16S rRNA gene clone libraries. $\varepsilon$-proteobacteria of the genus Arcobacter have also been shown to perform sulfur oxidation with denitrification in pure cultures (e.g., Gevertz et al., 2000) and in the environment (Lavik et al., 2009).

Our qPCR results indicate that $\gamma$-proteobacteria, mostly belonging to the SUP05 cluster, were particularly abundant in specific hydrothermal vent fluid samples (Hulk, ES (up to $38 \%$ ) and Cloud, AV (up to $26 \%$; Fig. 5). This finding was qualitatively supported by sequence abundances in 16S rRNA gene clone libraries. SUP05 is a clade of chemolitoautotrophic $\gamma$-proteobacteria capable of oxidizing reduced sulfur compounds using $\mathrm{NO}_{3}^{-}$as terminal electron acceptor (Lavik et al., 2009; Walsh al., 2009). A BLAST search revealed that SUP05 sequences were generally present in samples from hydrothermal vent systems, but had not been specifically identified as such in previous studies. For example, SUP05 sequences in this study shared a $99 \%$-similarity with a bacterial sequence from an iron oxide chimney-like structure on Volcano 19, in the South Tonga Arc, (accession (acc.) \#: FJ905679; Forget et al., 2010) and $98 \%$-similarity relative to sequences from the Suiyo Seamount hydrothermal plume (e.g., acc. \#: AB112459, AB112455 and AB112451) (Fig. 6). Moreover, bacteria of the SUP05 clade, which seem to only possess the nirK form of $\mathrm{NO}_{2}^{-}$reductase (Walsh et al., 2009) were generally more abundant than $\operatorname{nirS}$ genes based on qPCR assays, which represented up to $\sim 8 \%$ of the total bacterial abundance in hydrothermal vent fluids of the Juan de Fuca Ridge (A. Bourbonnais, unpublished). This suggests that SUP05 bacteria can represent an important fraction of the total denitrifying population in the subsurface biosphere of hydrothermal vent systems. It should be noted that because denitrifiers are highly diverse, it is virtually impossible to confirm the capacity of an organism to perform denitrification based solely on phylogenetic affiliation. Studies of the genes involved in the denitrification process, e.g., $\mathrm{NO}_{2}^{-}$reductase (nirS and nirK), and $\mathrm{N}_{2} \mathrm{O}$ reductase (nosZ) could represent a more direct approach to describing denitrifying bacterial communities from a functional perspective.

\subsection{Environmental controls on denitrifier (and anammox) activity and abundance}

Potential environmental controls on denitrifier activity and abundance in the subsurface biosphere of the Juan de Fuca hydrothermal vents can be evaluated by comparing measured microbiological attributes with physical, chemical and biological fluid properties.

$\mathrm{NO}_{2}^{-}$and $\mathrm{NO}_{3}^{-}$supply have been shown to stimulate denitrification and influence the distribution of denitrifying genes in marine, estuarine (e.g., Jayakumar et al., 2004; Dong et al., 2009) and terrestrial (e.g., Bradley et al., 1992; Smith et al., 2006; Opdyke et al., 2007; Zhong et al., 2010) environments. The significant negative relationship observed between denitrification rates and in situ $\mathrm{NO}_{3}^{-}$deficit (Spearman's $\rho=-0.55, \mathrm{p}$-value $=0.05$ ) suggests that $\mathrm{NO}_{3}^{-}$ supplied by mixing between $\mathrm{NO}_{3}^{-}$-poor hydrothermal fluids and $\mathrm{NO}_{3}^{-}$-rich crustal seawater may ultimately regulate denitrification in the subsurface biosphere of hydrothermal vents.

We also found a significant relationship between anammox rates and the DIN deficit, but this relationship should be interpreted with caution because of the limited number of measurements available for comparison (Fig. 7b). Previous studies have found that anammox was stimulated 
by $\mathrm{NH}_{4}^{+}, \mathrm{NO}_{2}^{-}$and/or $\mathrm{NO}_{3}^{-}$additions (e.g., Trimmer et al., 2005). No correlation was found between annamox rate and $\mathrm{NH}_{4}^{+}$deficit in this study. In fact, net $\mathrm{NH}_{4}^{+}$production seemed to be occurring, as indicated by a general $\mathrm{NH}_{4}^{+}$ surplus at most sites, probably through DNRA or organic matter decomposition. Our results suggest that, if anything, $\mathrm{NO}_{\mathrm{x}}$ rather than $\mathrm{NH}_{4}^{+}$modulates anammox rates in the vent fluids. Additionally, it should be noted that, in agreement with most recent observations from a mesotrophic Swiss lake (Wenk et al., 2013) we were able to measure low anammox rates, despite the high $\mathrm{H}_{2} \mathrm{~S}$ concentration of up to $1000 \mu \mathrm{mol} 1^{-1}$ in the fluids, suggesting that anammox growth is not completely inhibited by $\mathrm{H}_{2} \mathrm{~S}$, as previously suggested by Jensen et al. (2008).

Our molecular results suggest that sulfide-oxidizing denitrifiers represent a relatively large fraction of the total bacterial community at some subsurface hydrothermal environments. Sulfur driven autotrophic denitrification has been reported to be a significant process in other hydrothermal systems (López-García et al., 2003 and references therein). The lack of a significant relationship between denitrification rates and observed $\left[\mathrm{H}_{2} \mathrm{~S}\right]$ suggests that $\mathrm{H}_{2} \mathrm{~S}$ concentrations are not limiting denitrification. Furthermore, we cannot exclude that a portion of the total denitrification in hydrothermal vent fluids is heterotrophic. High heterotrophic denitrification rates have been measured in a similar (cold seep) environment (Bowles and Joye, 2011).

The fact that no correlations were observed between total microbial abundance (measured by DAPI counts and $\mathrm{qPCR}$ ) and denitrification rates suggests that, overall, denitrifiers represent only a minor fraction of the total microbial community. Indeed, in most samples, the relative abundance of SUP05 bacteria was less than $10 \%$ (except for Cloud, AV, 2007 (SUP05=26\%) and Hulk, ES, 2008 $($ SUP05 $=38 \%)$ Fig. 5$)$. The lack of significant correlations between denitrification rate and SUP05 abundances is also not surprising, because SUP05 bacteria probably only represent a portion of the total denitrifying community. Other potential candidates in our fluids include members of the $\varepsilon$-proteobacteria, as discussed in Sect. 4.2. Also, we only analysed the DNA fraction of the microbial community, not gene expression. However, there are generally delays observed between enzyme synthesis, expression and formation of denitrification products (e.g., see Baumann et al., 1996), such that it is generally difficult to directly relate gene transcriptional activity to denitrification rate measurements.

Other factors, e.g., $\mathrm{pH}$ and temperature, have been shown to influence $\mathrm{N}$ loss rates (e.g., Bradley et al., 1992; Opdyke et al., 2007; Zhong et al., 2010). In this study, no relationship was found between $\mathrm{pH}$ and temperature, and denitrification rates. Interestingly, higher temperatures did not seem to inhibit denitrification, suggesting the potential importance of mesophilic organisms in mediating $\mathrm{N}$-cycle processes in the subsurface biosphere. In fact, the highest denitrification rate $\left(\sim 1000 \mathrm{nmol} \mathrm{N}^{-1} \mathrm{day}^{-1}\right)$ was measured at Hermosa (AV), where the highest fluid temperature $\left(37^{\circ} \mathrm{C}\right)$ sampled in this study was observed.

\subsection{Total $N$ loss in the subsurface biosphere of diffuse hydrothermal vents}

Total $\mathrm{N}$ loss fluxes in hydrothermal vent systems are difficult to accurately quantify given the observed high variability of flow rates (e.g., Sarrazin et al., 2009) and our rudimentary knowledge of fluid residence times in the subsurface. Codispoti (2007) first estimated that $\sim 10 \mathrm{Tg} \mathrm{N}$ is lost every year during hydrothermal denitrification, assuming a hydrothermal flow associated with ridges and ridge flanks of $2.4 \times 10^{16} \mathrm{~kg} \mathrm{yr}^{-1}$ (Schultz and Elderfield, 1997), an initial average $\mathrm{NO}_{3}^{-}$concentration of $30 \mu \mathrm{moll}^{-1}$, and that denitrification occurs along the entire flow pathway. The latter assumption in particular may not be reasonable, as it includes the high- $T$ portion of the hydrothermal vent systems. Hence, this is likely a gross over-estimate of total net $\mathrm{N}$ loss in hydrothermal systems. On the other hand, Codispoti (2007) did not consider $\mathrm{N}_{2}$ fixation, which would add new $\mathrm{NO}_{3}^{-}$to hydrothermal vent fluids, compensating in part for $\mathrm{N}$ loss by denitrification, thus, allowing an even larger gross $\mathrm{N}$ loss. $\mathrm{N}_{2}$ fixation has indeed been reported to occur in hydrothermal vent fluids of the Juan de Fuca Ridge (e.g., Mehta and Baross, 2006).

Given recent advances in our understanding of the important role of the subsurface biosphere of diffuse hydrothemal vents in modulating geochemical fluxes in the deep ocean (e.g., Wankel et al., 2011; Bourbonnais et al., 2012), we attempt here to improve upon Codispoti's estimate and at least derive a possible range of values for gross global marine $\mathrm{N}$ loss occurring in the subsurface biosphere, based on denitrification rates measured in this study and current knowledge of hydrothermal flow and fluid residence times in the subsurface. We used the following equation to derive gross global $\mathrm{N}$ loss (in $\mathrm{Tg} \mathrm{yr}^{-1}$ ) in the subsurface biosphere of hydrothermal vents:

$\mathrm{N}$ loss $\left(\operatorname{Tg~} \mathrm{N} \mathrm{yr}^{-1}\right)=$ denitrification rate $\times$ volume flux

$$
x \text { residence time. }
$$

We used an average denitrification rate of $240 \mathrm{nmol} \mathrm{N}^{-1}$ day $^{-1}$ representative of all vent fields and years sampled in this study and a hydrothermal fluid volume flux of $6.3 \times 10^{15}$ to $1.6 \times 10^{16} 1^{-1} \mathrm{yr}^{-1}$, considering both axial $\left(10 \%\right.$ at $350{ }^{\circ} \mathrm{C}$ and $90 \%$ at $\left.5{ }^{\circ} \mathrm{C}\right)$ and off-axial $\left(5-15^{\circ} \mathrm{C}\right)$ hydrothermal flows (Elderfield and Schultz, 1996). We based our range of values for residence times on data from Johnson et al. (2010) and Foustoukos et al. (2009). Johnson et al. (2010) calculated a crustal residence time of $2.1 \mathrm{yr}$ (assuming $10 \%$ porosity) for the across-axis flow in the Endeavour Segment axial valley, Juan de Fuca Ridge, using conductive heat flow measurements. Foustoukos et 
al. (2009) estimated a crustal residence time of only a few tens of hours for the very shallow circulation cells feeding low- $\mathrm{T}$ diffuse vents adjacent to the Endeavour high-temperature fields, using $\mathrm{CO}_{2} / \mathrm{CO}$ equilibrium data. For our calculations, we assumed a range of residence times in the subsurface between $24 \mathrm{~h}$ and $2 \mathrm{yr}$, and assumed that only $5 \%$ to $25 \%$ of the subsurface hydrothermal system, including the recharge zone, is microbiologically active. Using this approach, we estimated that a range from 0.001 to 9.9 $\mathrm{Tg} \mathrm{N} \mathrm{yr}^{-1}$ could be removed globally by denitrification in hydrothermal vent systems.

Coincidently, our upper range of $\sim 10 \mathrm{Tg} \mathrm{yr}^{-1}$ for $\mathrm{N}$ loss in hydrothermal systems is the same as reported by Codispoti (2007), although his study did not measure denitrification rates. Our upper estimate is relatively low, when compared to estimates of the global ocean fixed $\mathrm{N}$ sink by benthic and water-column denitrification between $\sim 250$ to more than $400 \mathrm{Tg} \mathrm{Nyr}^{-1}$ for the global ocean (Gruber, 2004; Codispoti, 2007). We should note that our upper estimate may still be conservative, as it assumes that all denitrifying organisms are in the flowing water (i.e., not attached to surfaces in the flow path e.g., microbial mats). Our results nonetheless confirm the possible role of the subsurface biosphere in modulating geochemical fluxes in general, and fixed $\mathrm{N}$ fluxes, in particular.

\section{Summary and final remarks}

In this study we report, for the first time, potential denitrification, anammox and DNRA rates in diffuse hydrothermal vent fluids of the Juan de Fuca ridge. The activity of denitrifying bacteria in this subsurface biosphere and its prevalence over anammox and DNRA were confirmed by ${ }^{15} \mathrm{~N}$ paired isotope experiments at 13 different sites at Axial Volcano and the Endeavour Segment on the Juan de Fuca Ridge. Potential denitrification rates in subsurface hydrothermal vent fluids varied strongly in space and with time. The high denitrification potential observed at some sites (up to $\sim 1000 \mathrm{nmol} \mathrm{N1}^{-1}$ day $^{-1}$, Hermosa, AV) indicates that denitrification is a significant $\mathrm{N}$ sink in the subsurface biosphere of hydrothermal systems. Cloning and sequencing of the 16S rRNA genes revealed the dominance of $\varepsilon$ - and $\gamma$-proteobacteria in hydrothermal vent fluids, with the potential to oxidize sulfide or $\mathrm{H}_{2}$, using $\mathrm{NO}_{3}^{-}$as terminal electron acceptor. Our qPCR results indicated that a single cluster of $\gamma$-proteobacteria, i.e., the sulfur-oxidizing, $\mathrm{NO}_{3}^{-}$-reducing SUP05 bacteria, contributed up to $38 \%$ of the total bacterial population at some sites (Hulk, ES, 2008), implying a potentially important role for chemolithoautotrophic denitrification in hydrothermal vent fluids. While this study suggests that denitrification, possibly coupled to sulfide oxidation, is an important process in hydrothermal vents of the Juan de Fuca Ridge, more phylogenetic analysis of functional genes related to denitrification (e.g., nirS, nirK, nosZ) will be essential to better document and understand denitrifying microbial communities in the subsurface biosphere.

Our comprehension of environmental controls on $\mathrm{N}$ transformations in hydrothermal fluids is still very limited. In this study, denitrification, DNRA and anammox rates did not appear to be affected by most measured physicochemical factors. Significant negative relationships were only observed between denitrification, anammox rate and in situ $\mathrm{NO}_{3}^{-}$and DIN deficits, respectively. This implies that bioavailable inorganic $\mathrm{N}$ availability may ultimately regulate $\mathrm{N}$ loss and transformations in the subsurface biosphere of hydrothermal vents of the Juan de Fuca Ridge.

Combining potential rates from this study with published data on hydrothermal vent fluid residence times in the subsurface and annual seawater fluxes through these systems, we estimated that up to $\sim 10 \mathrm{Tg} \mathrm{N} \mathrm{yr}^{-1}$ could be removed by denitrification in the subsurface of the world's hydrothermal systems, suggesting that hydrothermal vent denitrification represents a minor, but significant fraction, of total marine fixed $\mathrm{N}$ loss.

\section{Supplementary material related to this article is available online at: http://www.biogeosciences.net/9/ 4661/2012/bg-9-4661-2012-supplement.zip.}

Acknowledgements. This work was supported by the Natural Sciences and Engineering Research Council (NSERC) of Canada, the National Oceanographic and Atmospheric Administration (NOAA), the Max-Planck-Gesellschaft, the Canada Foundation for Innovation (CFI), and the Canadian Institute for Advanced Research (CIFAR). A. B. benefited from an NSERC graduate fellowship and a PEO Scholar Award. S. K. J. was funded by an NSERC Discovery grant, M. F. L. by NSERC Discovery and SNF (Swiss National Science Foundation) R'Equip grants, D. A. B. was supported by U. S. N. S. F. grant OCE 0731947 and the NOAA/PMEL Vents Programme (JISAO contribution number 2028, PMEL contribution number 3835), and S. H. was supported by CFI and CIFAR. We thank James Holden, Bill Chadwick, the officers and crew of the R/V Atlantis and R/V Thomas $G$. Thompson, and the ROPOS, Jason and Alvin submersible teams for exceptional field support, and Rika Anderson, Karina Giesbreck, Mark Haught, Alyse Hawley, Kevin Roe, Réal Roy, Mark Rollog, Charles Stump, Elena Zaikova, and Jakob Zopfi for laboratory assistance. We also thank Julie Huber and Rika Anderson (John Baross' lab, University of Washington) and Helene C. Ver Eecke (James Holden's lab, University of Massachusetts) for sharing eDNA and bacterial count data, and Roberta Hamme for her help with denitrification rate measurements for the 2008 cruises. The CouchSurfing community provided accommodation for A. B. during sample analyses in Vancouver (Canada), Seattle (USA) and Bremen (Germany).

Edited by: T. Treude 


\section{References}

Alain, K., Zbinden, M., Le Bris, N., Lesongeur, F., Quérellou, J., Gaill, F., and Cambon-Bonavita, M. A.: Early steps in microbial colonization processes at deep-sea hydrothermal vents, Environ. Microbiol., 6, 227-241, 2004.

Altschul, S. F., Gish, W., Miller, W., Myers, E. W., and Lipman, D. J.: Basic local alignment search tool, J. Mol. Biol., 215, 403-410, 1990.

Ashelford, K. E., Chuzhanova, N. A., Fry, J. C., Jones, A. J., and Weightman, A. J.: New screening software shows that most recent large 16S rRNA gene clone libraries contain chimeras, Appl. Environ. Microbiol., 72, 5734-5741, 2006.

Bano, N. and Hollibaugh, J. T.: Phylogenetic composition of bacterioplankton assemblages from the Arctic Ocean, Appl. Environ. Microbiol., 68, 505-518, 2002.

Barwell-Clarke, J. and Whitney F.: Institute of Ocean Sciences nutrient methods and analysis, Can. Tech. Rep. Hydrogr. Ocean Sci., 182, 43 pp., 1996.

Baumann, B., Snozzi, M., Zehnder, A., and Van der Meer, J. R.: Dynamics of denitrification activity of Paracoccus denitrificans in continuous culture during aerobic-anaerobic changes, J. Bacteriol., 178, 4367-4374, 1996.

Betlach, M. R. and Tiedje, J. M.: Kinetic explanation for accumulation of nitrite, nitric oxide, and nitrous oxide during bacterial denitrification, Appl. Environ. Microbiol., 42, 1074-1084, 1981.

Bourbonnais, A., Lehmann, M. F., Butterfield, D. A., and Juniper, S. K.: Subseafloor nitrogen transformations in diffuse hydrothermal vent fluids of the Juan de Fuca Ridge evidenced by the isotopic composition of nitrate and ammonium, Geochem. Geophys. Geosyst., 13, Q02T01, doi:10.1029/2011GC003863, 2012.

Bowles, M. and Joye, S.: High rates of denitrification and nitrate removal in cold seep sediments, ISME J., 5, 565-567, 2011.

Bradley, P. M., Marjorie Aelion, C., and Vroblesky, D. A.: Influence of environmental factors on denitrification in sediment contaminated with JP-4 jet fuel, Ground Water, 30, 843-848, 1992.

Braman, R. S. and Hendrix, S. A.: Nanogram nitrite and nitrate determination in environmental and biological materials by vanadium (III) reduction with chemiluminescence detection, Anal. Chem., 61, 2715-2718, 1989.

Butterfield, D. A., Roe, K. K., Lilley, M. D., Huber, J. A., Baross, J. A., Embley, R. W., and Massoth, G. J.: Mixing, reaction and microbial activity in the sub-seafloor revealed by temporal and spatial variation in diffuse flow vents at Axial Volcano, Geoph. Monog. Series, 144, 269-289, 2004.

Byrne, N., Strous, M., Crépeau, V., Kartal, B., Birrien, J. L., Schmid, M., Lesongeur, F., Schouten, S., Jaeschke, A., and Jetten, M.: Presence and activity of anaerobic ammonium-oxidizing bacteria at deep-sea hydrothermal vents, ISME J., 3, 117-123, 2009.

Cabello, P., Roldán, M. D., and Moreno-Vivián, C.: Nitrate reduction and the nitrogen cycle in archaea, Microbiology, 150, 3527-3546, 2004.

Chadwick Jr., W. W., Nooner, S. L., Butterfield, D. A., and Lilley, M. D.: Seafloor deformation and forecasts of the April 2011 eruption at Axial Seamount, Nature Geosci., 5, 474-477, 2012.

Chao, A.: Nonparametric estimation of the number of classes in a population, Scand. J. Stat., 11, 265-270, 1984.
Christensen, J. P., Murray, J. W., Devol, A. H., and Codispoti, L. A.: Denitrification in continental shelf sediments has major impact on the oceanic nitrogen budget, Global Biogeochem. Cy., 1, 97116, 1987.

Cline, J. D.: Spectrophotometric determination of hydrogen sulfide in natural waters, Limnol. Oceanogr., 14, 454-458, 1969.

Codispoti, L. A.: An oceanic fixed nitrogen sink exceeding $400 \mathrm{Tg} \mathrm{Na}^{-1}$ vs. the concept of homeostasis in the fixednitrogen inventory, Biogeosciences, 4, 233-253, doi:10.5194/bg4-233-2007, 2007.

Codispoti, L., Brandes, J. A., Christensen, J., Devol, A., Naqvi, S., Paerl, H. W., and Yoshinari, T.: The oceanic fixed nitrogen and nitrous oxide budgets: Moving targets as we enter the anthropocene?, Scientia Marina, 65, 85-105, 2001.

Dalsgaard, T., Canfield, D. E., Petersen, J., Thamdrup, B., and Acuña-González, $\mathrm{J} .: \mathrm{N}_{2}$ production by the anammox reaction in the anoxic water column of Golfo Dulce, Costa Rica, Nature, 422, 606-608, 2003.

Devol, A., Uhlenhopp, A., Naqvi, S., Brandes, J., Jayakumar, D., Naik, H., Gaurin, S., Codispoti, L., and Yoshinari, T.: Denitrification rates and excess nitrogen gas concentrations in the Arabian Sea oxygen deficient zone, Deep-Sea Res. I, 53, 1533-1547, 2006.

Dong, L. F., Smith, C. J., Papaspyrou, S., Stott, A., Osborn, A. M., and Nedwell, D. B.: Changes in benthic denitrification, nitrate ammonification, and anammox process rates and nitrate and nitrite reductase gene abundances along an estuarine nutrient gradient (the Colne Estuary, United Kingdom), Appl. Environ. Microbiol., 75, 3171-3179, 2009.

Edmond, J. M., Measures, C., McDuff, R. E., Chan, L. H., Collier, R., Grant, B., Gordon, L. I., and Corliss, J. B.: Ridge crest hydrothermal activity and the balances of the major and minor elements in the ocean: the Galapagos data, Earth Planet. Sci. Lett., 46, 1-18, 1979.

Elderfield, H. and Schultz, A.: Mid-ocean ridge hydrothermal fluxes and the chemical composition of the ocean, Annu. Rev. Earth Planet. Sci., 24, 191-224, 1996.

Embley, R., Chadwick Jr., W., Clague, D., and Stakes, D.: 1998 eruption of axial volcano: Multibeam anomalies and sea-floor observations, Geophys. Res. Lett., 26, 3425-3428, 1999.

Emerson, S., Stump, C., Wilbur, D., and Quay, P.: Accurate measurement of $\mathrm{O}_{2}, \mathrm{~N}_{2}$, and $\mathrm{Ar}$ gases in water and the solubility of $\mathrm{N}_{2}$, Mar. Chem., 64, 337-347, 1999.

Forget, N., Murdock, S., and Juniper, S.: Bacterial diversity in Ferich hydrothermal sediments at two South Tonga Arc submarine volcanoes, Geobiology, 8, 417-432, 2010.

Foustoukos, D. I., Pester, N. J., Ding, K., and Seyfried Jr., W. E.: Dissolved carbon species in associated diffuse and focused flow hydrothermal vents at the Main Endeavour Field, Juan de Fuca Ridge: Phase equilibria and kinetic constraints, Geochem. Geophys. Geosyst., 10, Q10003, doi:10.1029/2009GC002472, 2009.

German, C. R., Bowen, A., Coleman, M., Honig, D., Huber, J. A., Jakuba, M. V., Kinsey, J. C., Kurz, M. D., Leroy, S., and McDermott, J. M.: Diverse styles of submarine venting on the ultraslow spreading Mid-Cayman Rise, P. Natl. Acad. Sci. USA, 107, 14020-14025, 2010.

Gevertz, D., Telang, A. J., Voordouw, G., and Jenneman, G. E.: Isolation and characterization of strains CVO and FWKOB, two 
novel nitrate-reducing, sulfide-oxidizing bacteria isolated from oil field brine, Appl. Environ. Microbiol., 66, 2491-2501, 2000.

Grote, J., Schott, T., Bruckner, C. G., Glöckner, F. O., Jost, G., Teeling, H., Labrenz, M. and Jürgens, K.: Genome and physiology of a model Epsilonproteobacterium responsible for sulfide detoxification in marine oxygen depletion zones, P. Natl. Acad. Sci. USA, 109, 506-510, 2012.

Gruber, N.: The dynamics of the marine nitrogen cycle and its influence on atmospheric $\mathrm{CO}_{2}$, in: The ocean carbon cycle and climate, edited by: Follows, M. and Oguz, T., NATO ASI Series, Kluwer Academic, Dordrecht, 97-148, 2004.

Guindon, S., Dufayard, J. F., Lefort, V., Anisimova, M., Hordijk, W., and Gascuel, O.: New algorithms and methods to estimate maximum-likelihood phylogenies: assessing the performance of PhyML 3.0, Syst. Biol., 59, 307-321, 2010.

Hodges, T. W. and Olson, J. B.: Molecular comparison of bacterial communities within iron-containing flocculent mats associated with submarine volcanoes along the Kermadec Arc., Appl. Environ. Microbiol., 75, 1650-1657, 2009.

Huber, J. A., Butterfield, D. A., and Baross, J. A.: Temporal changes in archaeal diversity and chemistry in a mid-ocean ridge subseafloor habitat, Appl. Environ. Microbiol., 68, 1585-1594, 2002

Huber, J. A., Mark Welch, D. B., Morrison, H. G., Huse, S. M., Neal, P. R., Butterfield, D. A., and Sogin, M. L.: Microbial population structures in the deep marine biosphere, Science, 318 , 97-100, 2007.

Huber, J. A., Cantin, H. V., Huse, S. M., Mark Welch, D. B., Sogin, M. L., and Butterfield, D. A.: Isolated communities of Epsilonproteobacteria in hydrothermal vent fluids of the Mariana Arc seamounts, FEMS Microbiol. Ecol., 73, 538-549, 2010.

Huber, T., Faulkner, G., and Hugenholtz, P.: Bellerophon: a program to detect chimeric sequences in multiple sequence alignments, Bioinformatics, 20, 2317-2319, 2004.

Humbert, S., Zopfi, J., and Tarnawski, S.-E.: Abundance of anammox bacteria in different wetland soils, Environ. Microbiol. Rep., 4, 484-490, 2012.

Inagaki, F., Takai, K., Nealson, K. H., and Horikoshi, K.: Sulfurovum lithotrophicum gen. nov. sp. nov. a novel sulfuroxidizing chemolithoautotroph within the $\varepsilon$-Proteobacteria isolated from Okinawa Trough hydrothermal sediments, Int. J. Syst. Evol. Microbiol., 54, 1477-1482, 2004.

Jannasch, H. W. and Mottl, M. J.: Geomicrobiology of deep-sea hydrothermal vents, Science, 229, 717-725, 1985.

Jayakumar, D. A., Francis, C. A., Naqvi, S. W. A., and Ward, B. B.: Diversity of nitrite reductase genes (nirS) in the denitrifying water column of the coastal Arabian Sea, Aquat. Microb. Ecol., 34, 69-78, 2004.

Jensen, M. M., Kuypers, M. M. M., Lavik, G., and Thamdrup, B.: Rates and regulation of anaerobic ammonium oxidation and denitrification in the Black Sea, Limnol. Oceanogr., 53, 23-36, 2008.

Jensen, M. M., Lam, P., Revsbech, N. P., Nagel, B., Gaye, B., Jetten, M. S. M., and Kuypers, M. M. M.: Intensive nitrogen loss over the Omani Shelf due to anammox coupled with dissimilatory nitrite reduction to ammonium, ISME J., 5, 1660-1670, 2011.

Johnson, H. P., Tivey, M. A., Bjorklund, T. A., and Salmi, M. S.: Hydrothermal circulation within the Endeavour Segment, Juan de Fuca Ridge, Geochem. Geophys. Geosyst, 11, Q05002,
doi:10.1029/2009GC002957, 2010.

Krebs, C. J.: Ecological methodology, 2 Edn., Addison-Welsey Educational Publishers, Inc., Menlo Park, CA, 620 pp., 1999.

Kuypers, M. M. M., Sliekers, A. O., Lavik, G., Schmid, M., Jørgensen, B. B., Kuenen, J. G., Damsté, J. S. S., Strous, M., and Jetten, M. S. M.: Anaerobic ammonium oxidation by anammox bacteria in the Black Sea, Nature, 422, 608-611, 2003.

Kuypers, M. M. M., Lavik, G., Woebken, D., Schmid, M., Fuchs, B. M., Amann, R., Jørgensen, B. B., and Jetten, M. S. M.: Massive nitrogen loss from the Benguela upwelling system through anaerobic ammonium oxidation, P. Natl. Acad. Sci. USA, 102, 6478-6483, 2005.

Lam, P., Lavik, G., Jensen, M. M., van de Vossenberg, J., Schmid, M., Woebken, D., Gutiérrez, D., Amann, R., Jetten, M. S. M., and Kuypers, M. M. M.: Revising the nitrogen cycle in the Peruvian oxygen minimum zone, P. Natl. Acad. Sci. USA, 106, 4752-4757, 2009.

Lavik, G., Stuhrmann, T., Bruchert, V., Van der Plas, A., Mohrholz, V., Lam, P., Mussmann, M., Fuchs, B. M., Amann, R., Lass, U., and Kuypers, M. M. M.: Detoxification of sulphidic African shelf waters by blooming chemolithotrophs, Nature, 457, 581-584, 2009.

Lilley, M. D., Butterfield, D. A., Olson, E. J., Lupton, J. E., Macko, S. A., and McDuff, R. E.: Anomalous $\mathrm{CH}_{4}$ and $\mathrm{NH}_{4}^{+}$concentrations at an unsedimented mid-ocean-ridge hydrothermal system, Nature, 364, 45-47, 1993.

López-García, P., Gaill, F., and Moreira, D.: Wide bacterial diversity associated with tubes of the vent worm Riftia pachyptila., Environ. Microbiol., 4, 204-215, 2002.

López-García, P., Duperron, S., Philippot, P., Foriel, J., Susini, J., and Moreira, D.: Bacterial diversity in hydrothermal sediment and epsilon proteobacterial dominance in experimental microcolonizers at the Mid-Atlantic Ridge, Environ. Microbiol., 5, 961-976, 2003.

Manning, C. C., Hamme, R. C., and Bourbonnais, A.: Impact of deep-water renewal events on fixed nitrogen loss from seasonally-anoxic Saanich Inlet, Mar. Chem., 122, 1-10, 2010.

Mehta, M. P. and Baross, J. A.: Nitrogen fixation at $92^{\circ} \mathrm{C}$ by a hydrothermal vent archaeon, Science, 314, 1783-1786, 2006.

Nakagawa, S., Takai, K., Inagaki, F., Hirayama, H., Nunoura, T., Horikoshi, K., and Sako, Y.: Distribution, phylogenetic diversity and physiological characteristics of epsilon-Proteobacteria in a deep-sea hydrothermal field, Environ. Microbiol., 7, 1619-1632, 2005a.

Nakagawa, S., Takai, K., Inagaki, F., Horikoshi, K., and Sako, Y.: Nitratiruptor tergarcus gen. nov. sp. nov. and Nitratifractor salsuginis gen. nov. sp. nov. nitrate-reducing chemolithoautotrophs of the $\varepsilon$-Proteobacteria isolated from a deep-sea hydrothermal system in the Mid-Okinawa Trough, Int. J. Syst. Evol. Microbiol., 55, 925-933, 2005b.

Nielsen, L. P.: Denitrification in sediment determined from nitrogen isotope pairing, FEMS Microbiol. Lett., 86, 357-362, 1992.

Opdyke, M. R. and David, M. B.: Response of sediment denitrification rates to environmental variables in streams heavily impacted by agriculture, J. Freshwat. Ecol., 22, 371-382, 2007.

Ravenschlag, K., Sahm, K., Pernthaler, J., and Amann, R.: High bacterial diversity in permanently cold marine sediments, Appl. Environ. Microbiol., 65, 3982-3989, 1999. 
Risgaard-Petersen, N., Meyer, R. L., and Revsbech, N. P.: Denitrification and anaerobic ammonium oxidation in sediments: effects of microphytobenthos and $\mathrm{NO}_{3}^{-}$, Aquat. Microb. Ecol., 40, 67-76, 2005.

Sarrazin, J., Rodier, P., Tivey, M. K., Singh, H., Schultz, A., and Sarradin, P. M.: A dual sensor device to estimate fluid flow velocity at diffuse hydrothermal vents, Deep-Sea Res. I, 56, 2065-2074, 2009.

Schloss, P. D., Westcott, S. L., Ryabin, T., Hall, J. R., Hartmann, M., Hollister, E. B., Lesniewski, R. A., Oakley, B. B., Parks, D. H., and Robinson, C. J.: Introducing mothur: open-source, platformindependent, community-supported software for describing and comparing microbial communities, Appl. Environ. Microbiol., 75, 7537-7541, 2009.

Schultz, A. and Elderfield, H.: Controls on the physics and chemistry of seafloor hydrothermal circulation, Philos. Tr. R. Soc. London S.-A, 355, 387-425, 1997.

Shao, M. F., Zhang, T., and Fang, H. H. P.: Sulfur-driven autotrophic denitrification: diversity, biochemistry, and engineering applications, Appl. Microbiol. Biotechnol., 88, 1027-1042, 2010.

Sievert, S. M., Scott, K. M., Klotz, M. G., Chain, P. S. G., Hauser, L. J., Hemp, J., Hügler, M., Land, M., Lapidus, A., and Larimer, F. W.: Genome of the epsilonproteobacterial chemolithoautotroph Sulfurimonas denitrificans, Appl. Environ. Microbiol., 74, 11451156, 2008.

Smith, L. K., Voytek, M. A., Böhlke, J. K., and Harvey, J. W.: Denitrification in nitrate-rich streams: application of $\mathrm{N}_{2}$ : Ar and ${ }^{15} \mathrm{~N}$-tracer methods in intact cores, Ecol. Appl., 16, 2191-2207, 2006.

Solorzano, L.: Determination of ammonia in natural waters by the phenolhypochlorite method, Limnol. Oceanogr., 14, 799-801, 1969.

Stevens, H. and Ulloa, O.: Bacterial diversity in the oxygen minimum zone of the eastern tropical South Pacific, Environ. Microbiol., 10, 1244-1259, 2008.

Stewart, F. J., Ulloa, O., and DeLong, E. F.: Microbial metatranscriptomics in a permanent marine oxygen minimum zone, Environ. Microbiol., 14, 23-40, 2012.

Strous, M., Fuerst, J. A., Kramer, E. H. M., Logemann, S., Muyzer, G., Van de Pas-Schoonen, K. T., Webb, R., Kuenen, J. G., and Jetten, M. S. M.: Missing lithotroph identified as new planctomycete, Nature, 400, 446-449, 1999.

Sunamura, M., Higashi, Y., Miyako, C., Ishibashi, J., and Maruyama, A.: Two bacteria phylotypes are predominant in the Suiyo seamount hydrothermal plume, Appl. Environ. Microbiol., 70, 1190-1198, 2004.

Takai, K., Suzuki, M., Nakagawa, S., Miyazaki, M., Suzuki, Y., Inagaki, F., and Horikoshi, K.: Sulfurimonas paralvinellae sp. nov. a novel mesophilic, hydrogen- and sulfur-oxidizing chemolithoautotroph within the Epsilonproteobacteria isolated from a deep-sea hydrothermal vent polychaete nest, reclassification of Thiomicrospira denitrificans as Sulfurimonas denitrificans comb. nov. and emended description of the genus Sulfurimonas, Int. J. Syst. Evol. Microbiol., 56, 1725-1733, 2006.

Thamdrup, B., Dalsgaard, T., Jensen, M. M., Ulloa, O., Farías, L., and Escribano, R.: Anaerobic ammonium oxidation in the oxygen-deficient waters off northern Chile, Limnol. Oceanogr., 51, 2145-2156, 2006.
Thompson, J. D., Higgins, D. G., and Gibson, T. J.: CLUSTAL $\mathrm{W}$ : improving the sensitivity of progressive multiple sequence alignment through sequence weighting, position-specific gap penalties and weight matrix choice, Nucleic. Acids Res., 22, 4673-4680, 1994.

Thompson, J. R., Marcelino, L. A., and Polz, M. F.: Heteroduplexes in mixed-template amplifications: formation, consequence and elimination by "reconditioning PCR", Nucleic. Acids Res., 30, 2083-2088, 2002.

Trimmer, M., Nicholls, J. C., Morley, N., Davies, C. A., and Aldridge, J.: Biphasic behaviour of anammox regulated by nitrite and nitrate in an estuarine sediment, Appl. Environ. Microbiol., 71, 1923-1930, 2005.

Walsh, D. A., Zaikova, E., Howes, C. G., Song, Y. C., Wright, J. J., Tringe, S. G., Tortell, P. D., and Hallam, S. J.: Metagenome of a versatile chemolithoautotroph from expanding oceanic dead zones, Science, 326, 578-582, 2009.

Wang, F., Zhou, H., Meng, J., Peng, X., Jiang, L., Sun, P., Zhang, C., Van Nostrand, J. D., Deng, Y., and He, Z.: GeoChip-based analysis of metabolic diversity of microbial communities at the Juan de Fuca Ridge hydrothermal vent, P. Natl. Acad. Sci. USA, 106, 4840-4845, 2009.

Wang, Q., Garrity, G. M., Tiedje, J. M., and Cole, J. R.: Naive Bayesian classifier for rapid assignment of rRNA sequences into the new bacterial taxonomy, Appl. Environ. Microbiol., 73, 5261-5267, 2007.

Wankel, S. D., Germanovich, L. N., Lilley, M. D., Genc, G., DiPerna, C. J., Bradley, A. S., Olson, E. J., and Girguis, P. R.: Influence of subsurface biosphere on geochemical fluxes from diffuse hydrothermal fluids, Nature Geosci., 4, 461-468, 2011.

Ward, B. B., Devol, A. H., Rich, J. J., Chang, B. X., Bulow, S. E., Naik, H., Pratihary, A., and Jayakumar, A.: Denitrification as the dominant nitrogen loss process in the Arabian Sea, Nature, 461, 78-81, 2009.

Weiss, R. F. and Price, B. A.: Nitrous oxide solubility in water and seawater, Mar. Chem., 8, 347-359, 1980.

Wenk, C. B., Blees, J., Zopfi, J., Veronesi, M., Bourbonnais, A., Schubert, C. J., Niemann, H., and Lehmann, M. F.: Anaerobic ammonium oxidation (anammox) bacteria and sulfide-dependent denitrifiers coexist in the water column of a meromictic south-alpine lake, Limnol. Oceanogr., 58, 1-12 doi:10.4319/lo.2013.58.1.0001, 2013.

Yayanos, A. A.: Microbiology to 10500 meters in the deep sea, Annu. Rev. Microbiol., 49, 777-805, 1995.

Zaikova, E., Walsh, D. A., Stilwell, C. P., Mohn, W. W., Tortell, P. D., and Hallam, S. J.: Microbial community dynamics in a seasonally anoxic fjord: Saanich Inlet, British Columbia, Environ. Microbiol., 12, 172-191, 2010.

Zhong, J., Fan, C., Liu, G., Zhang, L., Shang, J., and Gu, X.: Seasonal variation of potential denitrification rates of surface sediment from Meiliang Bay, Taihu Lake, China, J. Environ. Sci., 22, 961-967, 2010.

Zumft, W. G.: Cell biology and molecular basis of denitrification, Microbiol. Mol. Biol. Rev., 61, 533-616, 1997. 